\title{
Discrete Conjugated Poly(arylene ether) Compounds for Blue Emission Electroluminescent Devices
}

Hsin-Yi Wen", *, Tzu-Sheng Huang ", Huai-De Zhang", Mei-Ying Chang", * and WenYao Huang",

Department of Mechanical Engineering, National Kaohsiung University of Science and Technology, Kaohsiung 807, Taiwan

Department of Photonics, National Sun Yat-Sen University, Kaohsiung 804,

Taiwan

Hsin-Yi Went, ${ }^{*}$

E-mail: hywen@nkust.edu.tw

Wen-Yao Huang ${ }^{\ddagger}{ }^{*}$

E-mail: wyhuang@faculty.nsysu.edu.tw 


\section{Synthesis of Copolymer Compounds}

Scheme 1 shows the synthetic routes of PCzAn, PCzBAn, and PCzPy as well as mass spectrometer-recorded supporting information. The NMR, MALDI-TOF and FTIR of this series compounds, shown in Figure S1 to Figure S28. As Figure S28 presents FTIR spectra of three copolymers at $1605 \mathrm{~cm}^{-1}$ aryl ring quadrant stretch, at $1479,1277 \mathrm{~cm}^{-1}$ involves $\mathrm{CF}_{3}$ asymmetric stretch, 1243, $1181-1134 \mathrm{~cm}^{-1}$ involves $\mathrm{cm}^{-1} \mathrm{C}-\mathrm{O}$ asymmetric stretch, $1053 \mathrm{~cm}^{-1}$ assigned saturated aromatic C-O-C stretch for ether type.

\subsection{Synthesis of 3,6-dibromo-9H-carbazole}

9H-Carbazole $(10.0 \mathrm{~g}, 59.8 \mathrm{mmol})$ was dissolved in DMF $(150 \mathrm{~mL})$ in a cooled water bath at $0{ }^{\circ} \mathrm{C}$. NBS $(23.5 \mathrm{~g}, 132.0 \mathrm{mmol})$ was then dissolved in DMF (100 $\mathrm{mL}$ ), dropped into the $9 \mathrm{H}$-carbazole solution, and stirred for $2 \mathrm{~h}$. The mixture was then washed with deionized (DI) water $(600 \mathrm{~mL})$, and the white crystals were extracted. Finally, the mixture was purified through recrystallization with EA and n-hexane. ${ }^{1} \mathrm{H}-\mathrm{NMR}\left(500 \mathrm{MHz}, \mathrm{CDCl}_{3}, 25{ }^{\circ} \mathrm{C}\right): \mathrm{d}(\mathrm{ppm}) 8.138(\mathrm{~d}, \mathrm{~J}=2$ $\mathrm{Hz}, 1 \mathrm{H}), 7.534-7.513(\mathrm{~m}, \mathrm{~J}=8.5 \mathrm{~Hz}, 2 \mathrm{H})$, and $7.317(\mathrm{~d}, \mathrm{~J}=8.5 \mathrm{~Hz}, 2 \mathrm{H})$. 
3,6-Dibromo-9H-carbazole $(15.0 \mathrm{~g}, 46.15 \mathrm{mmol})$ and potassium carbonate $(19.0 \mathrm{~g}, 137.5 \mathrm{mmol})$ were dissolved in DMF $(200 \mathrm{~mL})$ and heated at $110{ }^{\circ} \mathrm{C}$. Then, 1-bromohexane (11.4 g, $69.0 \mathrm{mmol})$ was slowly dropped into the mixture solution and stirred for 1 day. The mixture was then washed with DI water (600 $\mathrm{mL}$ ), and white crystals were extracted. Finally, the mixture was purified through recrystallization with EA and n-hexane. ${ }^{1} \mathrm{H}-\mathrm{NMR}\left(500 \mathrm{MHz}, \mathrm{CDCl} 3,25{ }^{\circ} \mathrm{C}\right)$ : d (ppm) $8.14(\mathrm{~s}, 1 \mathrm{H}), 7.55(\mathrm{~d}, \mathrm{~J}=10.0 \mathrm{~Hz}, 2 \mathrm{H}), 7.27(\mathrm{~d}, \mathrm{~J}=10.0 \mathrm{~Hz}, 2 \mathrm{H}), 4.26-$ $4.23(\mathrm{~m}, 2 \mathrm{H}), 1.84(\mathrm{~m}, 2 \mathrm{H}), 1.56-1.27(\mathrm{~m}, 6 \mathrm{H})$, and $0.87-0.84(\mathrm{~m}, 1 \mathrm{H})$.

\subsection{Synthesis of 9-hexyl-3,6-bis(4-methoxyphenyl)-9H-carbazole}

3,6-Dibromo-9-hexyl-9H-carbazole $(7.0 \mathrm{~g}, 17.11 \mathrm{mmol})$ and 4methoxyphenylboronic acid $(7.8 \mathrm{~g}, 51.33 \mathrm{mmol})$ were dissolved in the mixture comprising toluene (120 mL), THF (15 mL), and ethanol (12 mL) under a $\mathrm{N}_{2}$ atmosphere. Then, $\mathrm{K}_{2} \mathrm{CO}_{3}(9.5 \mathrm{~g}, 68.74 \mathrm{mmol})$ was dissolved in DI water (21 $\mathrm{mL}$ ) and added into the mixture solution. When the mixture was boiled, (AtaPhos) ${ }_{2} \mathrm{PdCl}_{2}$ and $\mathrm{Pd}($ amphos $) \mathrm{Cl}_{2}{ }^{29}$ (catalyst, $120 \mathrm{mg}, 0.17 \mathrm{mmol}$ ) were added and stirred for 2 days. Moreover, toluene and saturated saline were used to extract the organic layer. Any impurity was removed from the mixture by using activated carbon, and the mixture was filtrated using $\mathrm{Na}_{2} \mathrm{SO}_{4}$. Finally, the resulting product was obtained through reduced pressure distillation. The resulting product was purified through recrystallization with THF and n-hexane. ${ }^{1} \mathrm{H}-\mathrm{NMR}\left(500 \mathrm{MHz}, \mathrm{CDCl} 3,25{ }^{\circ} \mathrm{C}\right): \mathrm{d}(\mathrm{ppm}) 8.28(\mathrm{~d}, \mathrm{~J}=1.5 \mathrm{~Hz}, 2 \mathrm{H}), 7.68(\mathrm{~d}, \mathrm{~J}$ 
$=1.5 \mathrm{~Hz}, 2 \mathrm{H}), 7.50(\mathrm{~d}, \mathrm{~J}=9.0 \mathrm{~Hz}, 2 \mathrm{H}), 7.45(\mathrm{~d}, \mathrm{~J}=8.5 \mathrm{~Hz}, 2 \mathrm{H}), 7.02(\mathrm{~d}, \mathrm{~J}=9.0$ $\mathrm{Hz}, 4 \mathrm{H}), 4.44-4.43(\mathrm{~m}, 2 \mathrm{H}), 3.88(\mathrm{~s}, 6 \mathrm{H}), 1.91(\mathrm{~m}, 2 \mathrm{H}), 1.47-1.26(\mathrm{~m}, 6 \mathrm{H})$, and $0.89-0.86(m, 3 H)$.

3.4 Synthesis of 4,4'-(9-hexyl-9H-carbazole-3,6-diyl) diphenol (Cz)

9-Hexyl-3,6-bis(4-methoxyphenyl)-9H-carbazole (5 g, $10.79 \mathrm{mmol}$ ) was dissolved in DCM (35 mL). Boron tribromide $(3.1 \mathrm{~mL}, 32.36 \mathrm{mmol})$ was then injected at $-78{ }^{\circ} \mathrm{C}$, and the solution was stirred for 1 day. Extraction was performed using EA and DI water, and dewatering was performed using $\mathrm{Na}_{2} \mathrm{SO}_{4}$. Finally, the resulting product was obtained through reduced pressure distillation. ${ }^{1} \mathrm{H}-\mathrm{NMR}\left(500 \mathrm{MHz}, \mathrm{CDCl}_{3}, 25{ }^{\circ} \mathrm{C}\right): \mathrm{d}(\mathrm{ppm}) 8.77(\mathrm{~d}, \mathrm{~J}=1.5 \mathrm{~Hz}, 1 \mathrm{H})$, $7.66(\mathrm{~d}, \mathrm{~J}=8.5 \mathrm{~Hz}, 1 \mathrm{H}), 7.61-7.58(\mathrm{~m}, 2 \mathrm{H}), 7.35(\mathrm{~d}, \mathrm{~J}=8.5 \mathrm{~Hz}, 1 \mathrm{H})$, and 6.95 (d, $\mathrm{J}=7.5 \mathrm{~Hz}, 2 \mathrm{H}$ ). MALDI-TOF/TOF MS (m/z): Calcd. For $\mathrm{C}_{30} \mathrm{H}_{29} \mathrm{NO}_{2}: 435.57$, found. 435.14 .

3.5 Synthesis of 9, 10-bis(4-fluoro-3-(trifluoromethyl)phenyl) anthracene (An)

9,10-Dibromoanthracene ( $3 \mathrm{~g}, 8.93 \mathrm{mmol}$ ) and 4-fluoro-3-(trifluoromethyl) phenylboronic acid $(4.08 \mathrm{~g}, 19.62 \mathrm{mmol})$ were dissolved in toluene $(200 \mathrm{~mL})$ and THF (50 mL) under a $\mathrm{N}_{2}$ atmosphere. $\mathrm{K}_{2} \mathrm{CO}_{3}(4.93 \mathrm{~g}, 35.72 \mathrm{mmol})$ in $\mathrm{DI}$ water $(16 \mathrm{~mL})$ was then added to the mixture. Then, when the mixture was boiled, (A-taPhos) ${ }_{2} \mathrm{PdCl}_{2}$ and $\mathrm{Pd}\left(\right.$ amphos) $\mathrm{Cl}_{2}$ (catalyst, $30 \mathrm{mg}, 0.042 \mathrm{mmol}$ ) were added, and the solution was stirred for 2 days. Moreover, toluene and 
saturated saline were used to extract the organic layer. Any impurity in the mixture was removed using activated carbon, and the mixture was filtrated using $\mathrm{Na}_{2} \mathrm{SO}_{4}$. Finally, the resulting product was obtained through reduced pressure distillation. The resulting product was purified through recrystallization with THF and n-hexane. ${ }^{1} \mathrm{H}-\mathrm{NMR}\left(500 \mathrm{MHz}^{\mathrm{CDCl}} 3,25{ }^{\circ} \mathrm{C}\right): \mathrm{d}(\mathrm{ppm}) 7.73(\mathrm{~d}, \mathrm{~J}=$ $10.0 \mathrm{~Hz}, 1 \mathrm{H}), 7.68-7.58(\mathrm{~m}, 1 \mathrm{H}), 7.60-7.58(\mathrm{~m}, 2 \mathrm{H}), 7.50-7.47(\mathrm{~m}, 1 \mathrm{H})$, and 7.44-7.41 (m, 2H). MALDI-TOF/TOF MS (m/z): Calcd. For $\mathrm{C}_{28} \mathrm{H}_{14} \mathrm{~F}_{8}: 502.14$, found. 501.93 .

3.6 Synthesis of 10,10'-bis(4-fluoro-3-(trifluoromethyl) phenyl)-9,9'-bianthracene $(B A n)$ 10,10'-Dibromo-9,9'-bianthracene (5 g, $9.76 \mathrm{mmol}$ ) and 4-fluoro-3(trifluoromethyl) phenylboronic acid $(5.48 \mathrm{~g}, 26.36 \mathrm{mmol})$ were dissolved in toluene $(250 \mathrm{~mL})$, THF $(130 \mathrm{~mL})$, and ethanol $(40 \mathrm{~mL})$ under a $\mathrm{N}_{2}$ atmosphere. $\mathrm{K}_{2} \mathrm{CO}_{3}(5.4 \mathrm{~g}, 39.07 \mathrm{mmol})$ in $\mathrm{DI}$ water $(17.76 \mathrm{~mL})$ was then added into the mixture solution. When the mixture was boiled, (A-taPhos) ${ }_{2} \mathrm{PdCl}_{2}$ and $\mathrm{Pd}$ (amphos) $\mathrm{Cl}_{2}$ (catalyst, $100 \mathrm{mg}, 0.14 \mathrm{mmol}$ ) were added, and the mixture was stirred for 2 days. Moreover, toluene and saturated saline was used to extract the organic layer. Any impurity in the mixture was removed using activated carbon, and the mixture was filtrated using $\mathrm{Na}_{2} \mathrm{SO}_{4}$. Finally, the resulting product was obtained through reduced pressure distillation. The resulting product was purified through recrystallization with THF and n-hexane. ${ }^{1} \mathrm{H}-\mathrm{NMR}$ 
$\left(500 \mathrm{MHz}, \mathrm{CDCl}_{3}, 25{ }^{\circ} \mathrm{C}\right): \mathrm{d}(\mathrm{ppm}) 8.94(\mathrm{~d}, \mathrm{~J}=6.5 \mathrm{~Hz}, 1 \mathrm{H}), 7.84-7.82(\mathrm{~m}, 1 \mathrm{H})$, $7.70(\mathrm{~d}, \mathrm{~J}=9.0 \mathrm{~Hz}, 2 \mathrm{H}), 7.54(\mathrm{t}, \mathrm{J}=10.0 \mathrm{~Hz}, 1 \mathrm{H}), 7.40-7.26(\mathrm{~m}, 2 \mathrm{H}), 7.24-7.20$ (m, 4H). MALDI-TOF/TOF MS (m/z): Calcd. For $\mathrm{C}_{42} \mathrm{H}_{22} \mathrm{~F}_{8}:$ 678.63, found. 677.93

\subsection{Synthesis of 1,6-bis(4-fluoro-3-(trifluoromethyl)phenyl) pyrene (Py)}

1,6-Dibromopyrene (3 g, $8.34 \mathrm{mmol})$ and 4-fluoro-3-(trifluoromethyl) phenylboronic acid (4.68 g, $22.52 \mathrm{mmol})$ was dissolved in toluene $(160 \mathrm{~mL})$, THF (65 mL), and ethanol ( $35 \mathrm{~mL})$ under a $\mathrm{N}_{2}$ atmosphere. $\mathrm{K}_{2} \mathrm{CO}_{3}(4.6 \mathrm{~g}, 18.35$ $\mathrm{mmol})$ in DI water $(15.16 \mathrm{~mL})$ was then added into the mixture solution. When the mixture was boiled, (A-taPhos) ${ }_{2} \mathrm{PdCl}_{2}$ and $\mathrm{Pd}\left(\right.$ amphos) $\mathrm{Cl}_{2}$ (catalyst, $75 \mathrm{mg}$, $0.106 \mathrm{mmol}$ ) were added, and the solution was stirred for 2 days. Moreover, toluene and saturated saline were used to extract the organic layer. Any impurity in the mixture was removed using activated carbon, and the mixture was filtrated using $\mathrm{Na}_{2} \mathrm{SO}_{4}$. Finally, the resulting product was obtained through reduced pressure distillation. The resulting product was purified through recrystallization with THF and n-hexane. ${ }^{1} \mathrm{H}-\mathrm{NMR}\left(500 \mathrm{MHz}, \mathrm{CDCl}_{3}, 25{ }^{\circ} \mathrm{C}\right): \mathrm{d}$ (ppm) $8.94(\mathrm{~d}, \mathrm{~J}=6.5 \mathrm{~Hz}, 1 \mathrm{H}), 7.84-7.82(\mathrm{~m}, 1 \mathrm{H}), 7.70(\mathrm{~d}, \mathrm{~J}=9.0 \mathrm{~Hz}, 2 \mathrm{H}), 7.54$ (t, $J=10.0 \mathrm{~Hz}, 1 \mathrm{H}), 7.40-7.26(\mathrm{~m}, 2 \mathrm{H})$, and 7.24-7.20 (m, 4H). MALDITOF/TOF MS (m/z): Calcd. For $\mathrm{C}_{42} \mathrm{H}_{22} \mathrm{~F}_{8}: 526.43$, found. 525.96 . 
$\mathrm{Cz}(1.00 \mathrm{~g}, 2.296 \mathrm{mmol}), \mathrm{An}(1.154 \mathrm{~g}, 2.297 \mathrm{mmol}), \mathrm{K}_{2} \mathrm{CO}_{3}(0.8 \mathrm{~g}, 5.788 \mathrm{mmol})$, and set Dean-Stark trap were introduced into the solvent, that is, DMAc $(35 \mathrm{~mL})$ and toluene $(15 \mathrm{~mL})$, and the mixture was heated to $110{ }^{\circ} \mathrm{C}$ under a $\mathrm{N}_{2}$ atmosphere. The solution was dewatered using toluene, heated to $160{ }^{\circ} \mathrm{C}$, and stirred for 1 day. After the reaction was completed, the solution was cooled to room temperature, and methanol was added for extraction. It was then washed using DI water and $\mathrm{n}$-hexane. The mixture was filtrated and redissolved in THF, extracted using methanol, and washed using DI water and n-hexane. This process was repeated five times. Finally, the resulting product was obtained using a vacuum drying oven $\left(80{ }^{\circ} \mathrm{C}\right)$. GPC: $\mathrm{Mw}=80,000 ; \mathrm{Mn}=17,800 ; \mathrm{Mw} / \mathrm{Mn}$ $=4.5 .{ }^{1} \mathrm{H}-\mathrm{NMR}: \mathrm{d}(\mathrm{ppm}) 8.39(\mathrm{~s}, 1 \mathrm{H}), 7.81-7.80(\mathrm{~m}, 3 \mathrm{H}), 7.75-7.74(\mathrm{~m}, 1 \mathrm{H})$, 7.73-7.69 (m, 2H), 7.58-7.56 (m, 1H), 7.51-7.49 (m, 1H), $7.44(\mathrm{~m}, 2 \mathrm{H})$, and $7.35(\mathrm{~d}, \mathrm{~J}=8.5 \mathrm{~Hz}, 2 \mathrm{H})$.

\subsection{Synthesis of PCzBAn copolymer}

$\mathrm{Cz}(1.00 \mathrm{~g}, 2.296 \mathrm{mmol}), \mathrm{BAn}(1.154 \mathrm{~g}, 2.297 \mathrm{mmol}), \mathrm{K}_{2} \mathrm{CO}_{3}(0.8 \mathrm{~g}, 5.788$ $\mathrm{mmol}$ ), and set Dean-Stark trap were introduced into the solvent, that is, DMAc (35 mL) and toluene $(15 \mathrm{~mL})$, and the mixture was heated to $110{ }^{\circ} \mathrm{C}$ under a $\mathrm{N}_{2}$ atmosphere. It was then dewatered using toluene, heated to $160{ }^{\circ} \mathrm{C}$, and stirred for 1 day. After the reaction was completed, the mixture was cooled to room temperature, and methanol was added for extraction. Furthermore, the mixture was washed using DI water and n-hexane. The mixture was filtrated and 
redissolved in THF, extracted by methanol, and washed using DI water and nhexane. The process was repeated a few times. The resulting product was then obtained using a vacuum drying oven $\left(80^{\circ} \mathrm{C}\right)$. GPC: $\mathrm{Mw}=133,000 ; \mathrm{Mn}=$ 33,300; $\mathrm{Mw} / \mathrm{Mn}=4.0 .{ }^{1} \mathrm{H}-\mathrm{NMR}: \mathrm{d}(\mathrm{ppm}) 8.42(\mathrm{~s}, 1 \mathrm{H}), 7.97(\mathrm{~s}, 1 \mathrm{H}), 7.85-7.73$ (m, 3H), 7.53-7.51 (m, 1H), 7.40-7.39 (m, 4H), 7.34-7.32 (m, 1H), and 7.25$7.15(\mathrm{~m}, 6 \mathrm{H})$.

\subsection{Synthesis of PCzPy copolymer}

$\mathrm{Cz}(1.00 \mathrm{~g}, 2.296 \mathrm{mmol}), \mathrm{Py}(1.209 \mathrm{~g}, 2.297 \mathrm{mmol}), \mathrm{K}_{2} \mathrm{CO}_{3}(0.8 \mathrm{~g}, 5.788 \mathrm{mmol})$, and set Dean-Stark trap were introduced into the solvent, that is, DMAc $(35 \mathrm{~mL})$ and toluene $(15 \mathrm{~mL})$, and the mixture was heated to $110{ }^{\circ} \mathrm{C}$ under a $\mathrm{N}_{2}$ atmosphere. It was then dewatered using toluene, heated to $160{ }^{\circ} \mathrm{C}$, and stirred for 1 day. After the reaction was completed, the mixture was cooled to room temperature, and methanol was added for extraction. The mixture was washed using DI water and n-hexane. It was then filtrated, redissolved in THF, extracted using methanol, and washed using DI water and $n$-hexane. This process was repeated a few times. Finally, the resulting product was obtained using a vacuum drying oven $\left(80{ }^{\circ} \mathrm{C}\right)$. GPC: $\mathrm{Mw}=128,000 ; \mathrm{Mn}=356,000 ; \mathrm{Mw} / \mathrm{Mn}=3.6$. ${ }^{1} \mathrm{H}-\mathrm{NMR}: \mathrm{d}(\mathrm{ppm}) 8.37(\mathrm{~s}, 1 \mathrm{H}), 8.21(\mathrm{~m}, 1 \mathrm{H}), 8.14-8.13(\mathrm{~m}, 1 \mathrm{H}), 8.08-8.07(\mathrm{~m}$, 1H), $7.96(\mathrm{~s}, 2 \mathrm{H}), 7.78-7.72(\mathrm{~m}, 4 \mathrm{H}), 7.48-7.47(\mathrm{~m}, 1 \mathrm{H}), 7.30-7.25(\mathrm{~m}, 4 \mathrm{H})$, and $7.22-7.20(\mathrm{~m}, 1 \mathrm{H})$. 


\section{EXPERIMENTAL DETAILS}

\section{Materials synthesis}

We also measured the FTIR, ${ }^{1} \mathrm{H}$ NMR and MALDI-TOF of this series compounds, shown in Figure $\mathrm{S} 1$ to Figure S28.

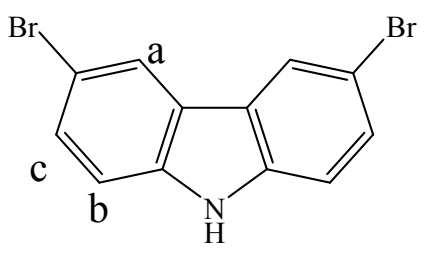

3,6-dibromo-9H-carbazole

Molecular Weight: 325.00 


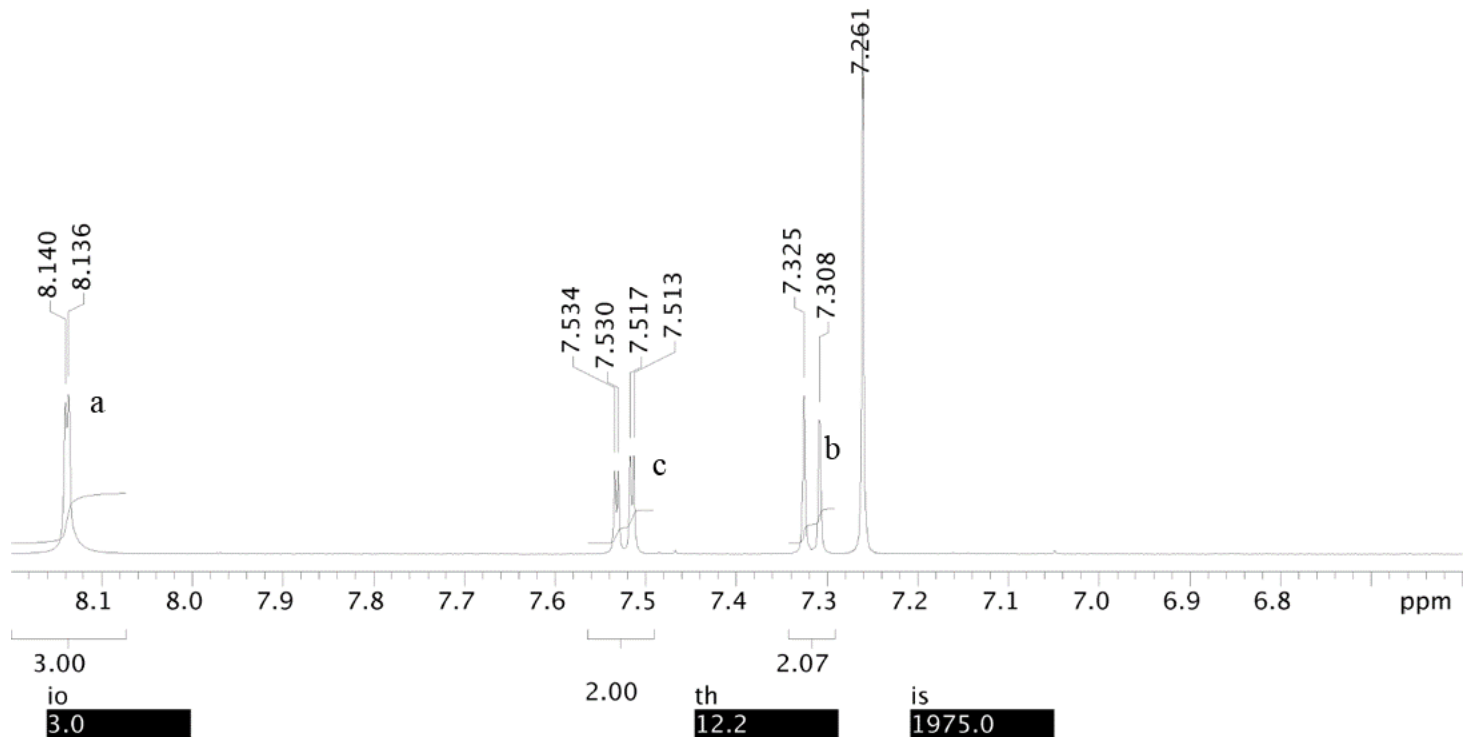

Figure S1. ${ }^{1} \mathrm{H}$ NMR spectrum of 3,6-dibromo-9H-carbazole from $6.6 \mathrm{ppm}$ to $8.2 \mathrm{ppm}$. 


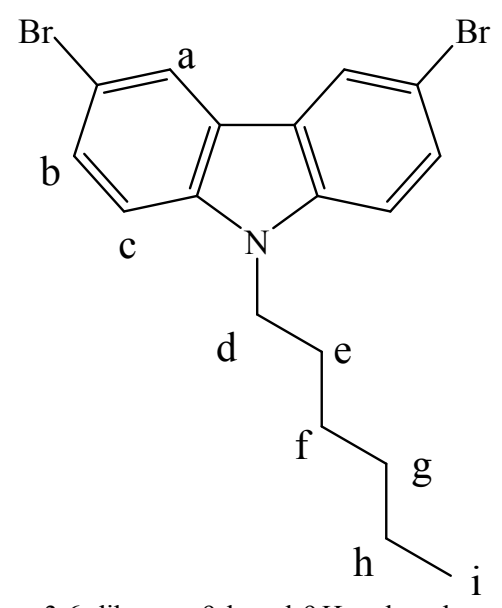

3,6-dibromo-9-hexyl-9H-carbazole

Molecular Weight: 409.17

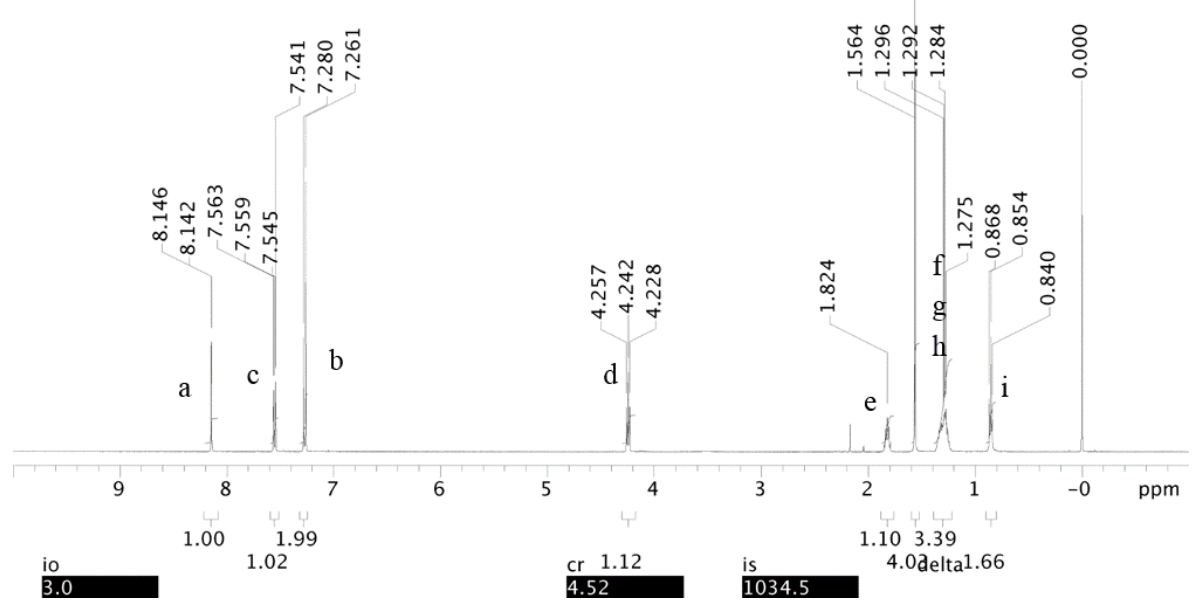

Figure S2. ${ }^{1} \mathrm{H}$ NMR spectrum of 3,6-dibromo-9-hexyl-9H-carbazole from 0 ppm to $10 \mathrm{ppm}$.

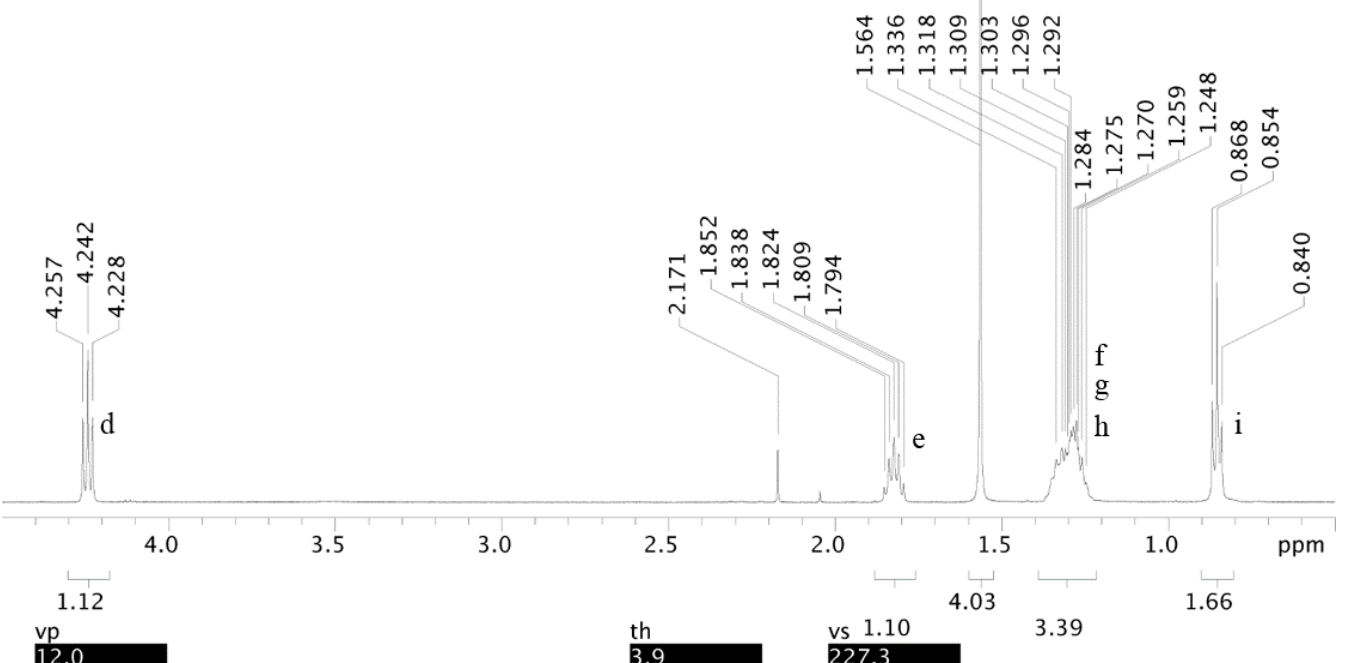

Figure S3. ${ }^{1} \mathrm{H}$ NMR spectrum of 3,6-dibromo-9-hexyl-9H-carbazole from $0 \mathrm{ppm}$ to $4.5 \mathrm{ppm}$. 


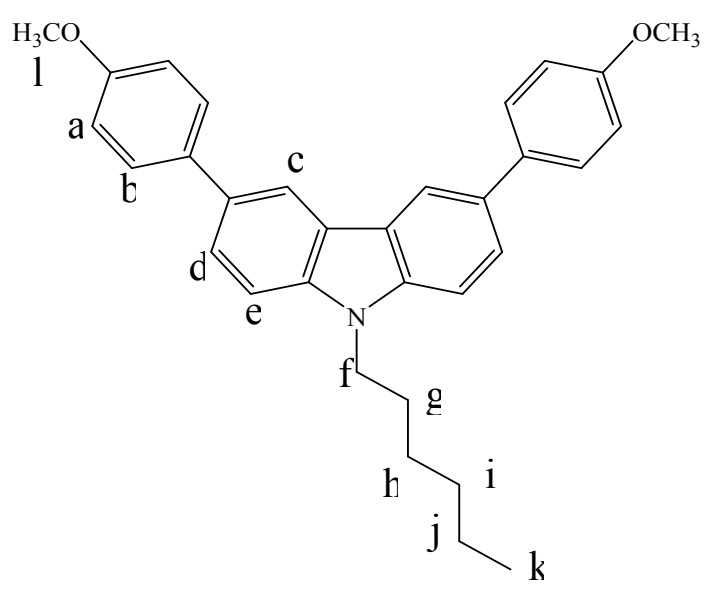

9-hexyl-3,6-bis(4-methoxyphenyl)-9H-carbazole

Molecular Weight: 463.62

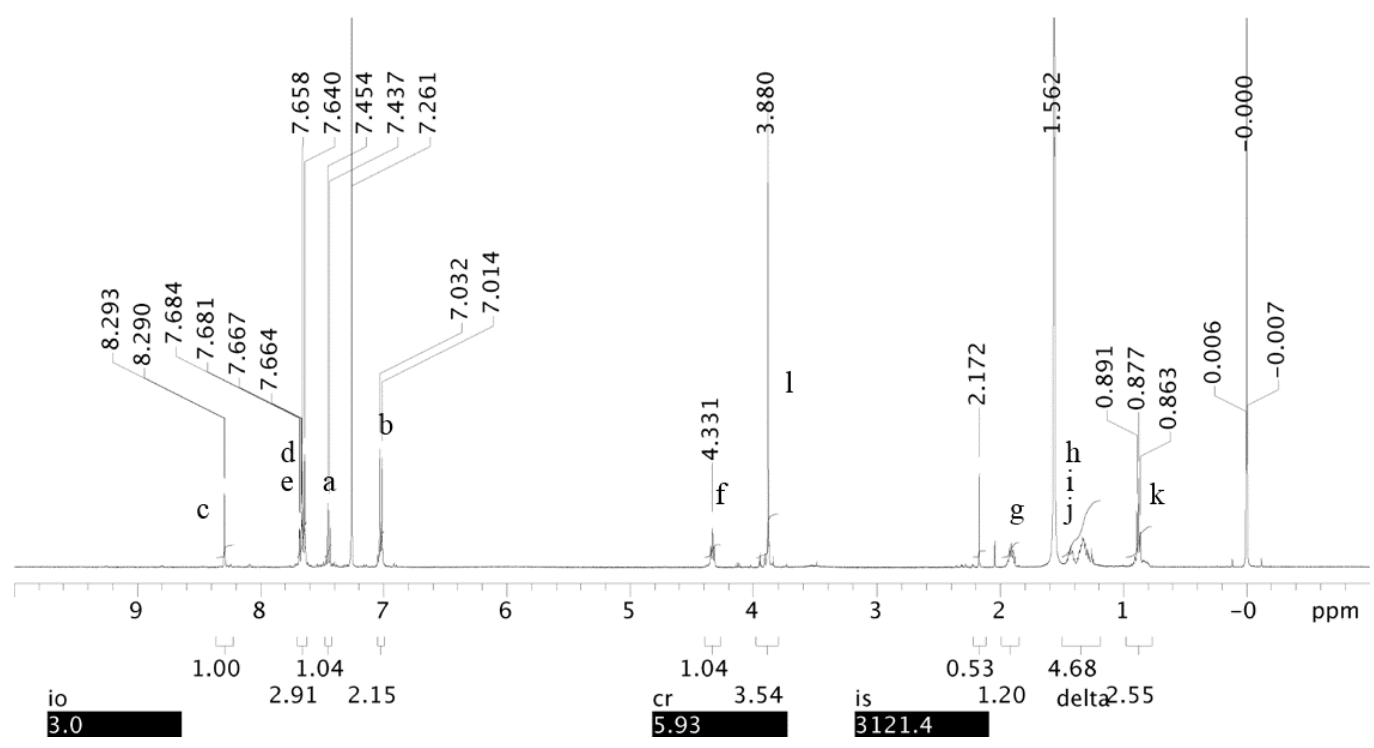

Figure S4. ${ }^{1} \mathrm{H}$ NMR spectrum of 9-hexyl-3,6-bis(4-methoxyphenyl)-9H-carbazole from $0 \mathrm{ppm}$ to $10 \mathrm{ppm}$.

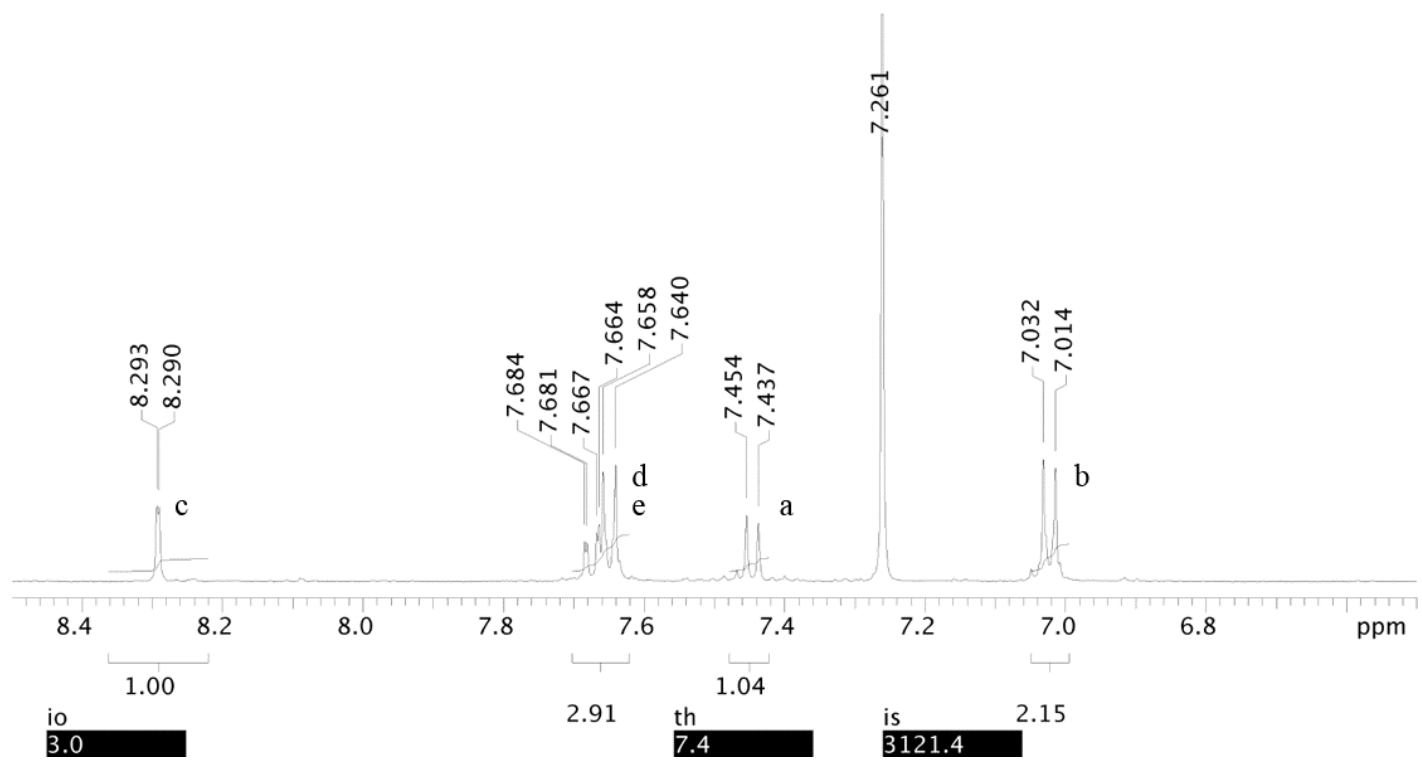

Figure S5. ${ }^{1} \mathrm{H}$ NMR spectrum of 9-hexyl-3,6-bis(4-methoxyphenyl)-9H-carbazole from $6.5 \mathrm{ppm}$ to $8.5 \mathrm{ppm}$. 

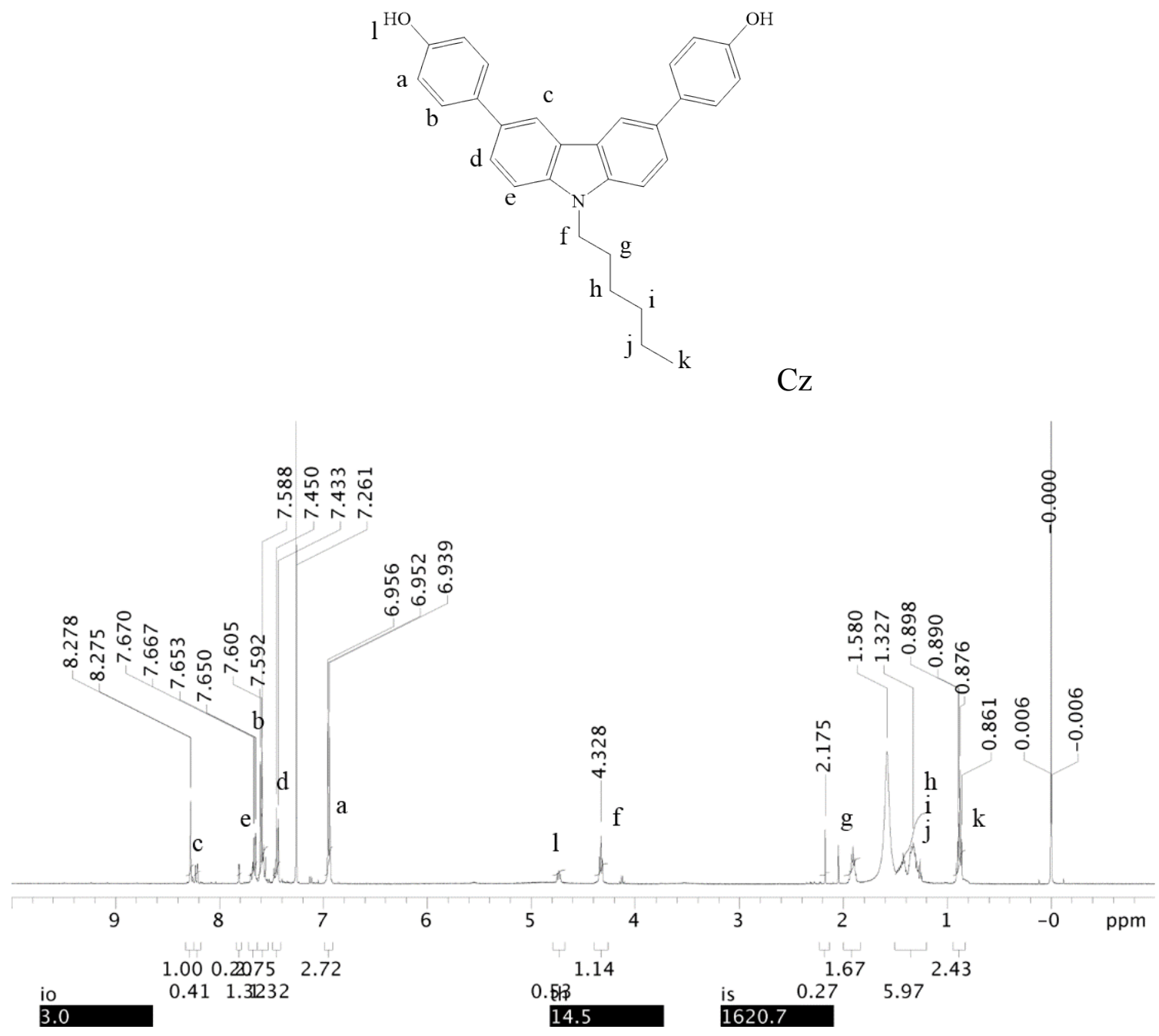

Figure S6. ${ }^{1} \mathrm{H}$ NMR spectrum of 4,4'-(9-hexyl-9H-carbazole-3,6-diyl)diphenol (Cz) from 0 ppm to $10 \mathrm{ppm}$.

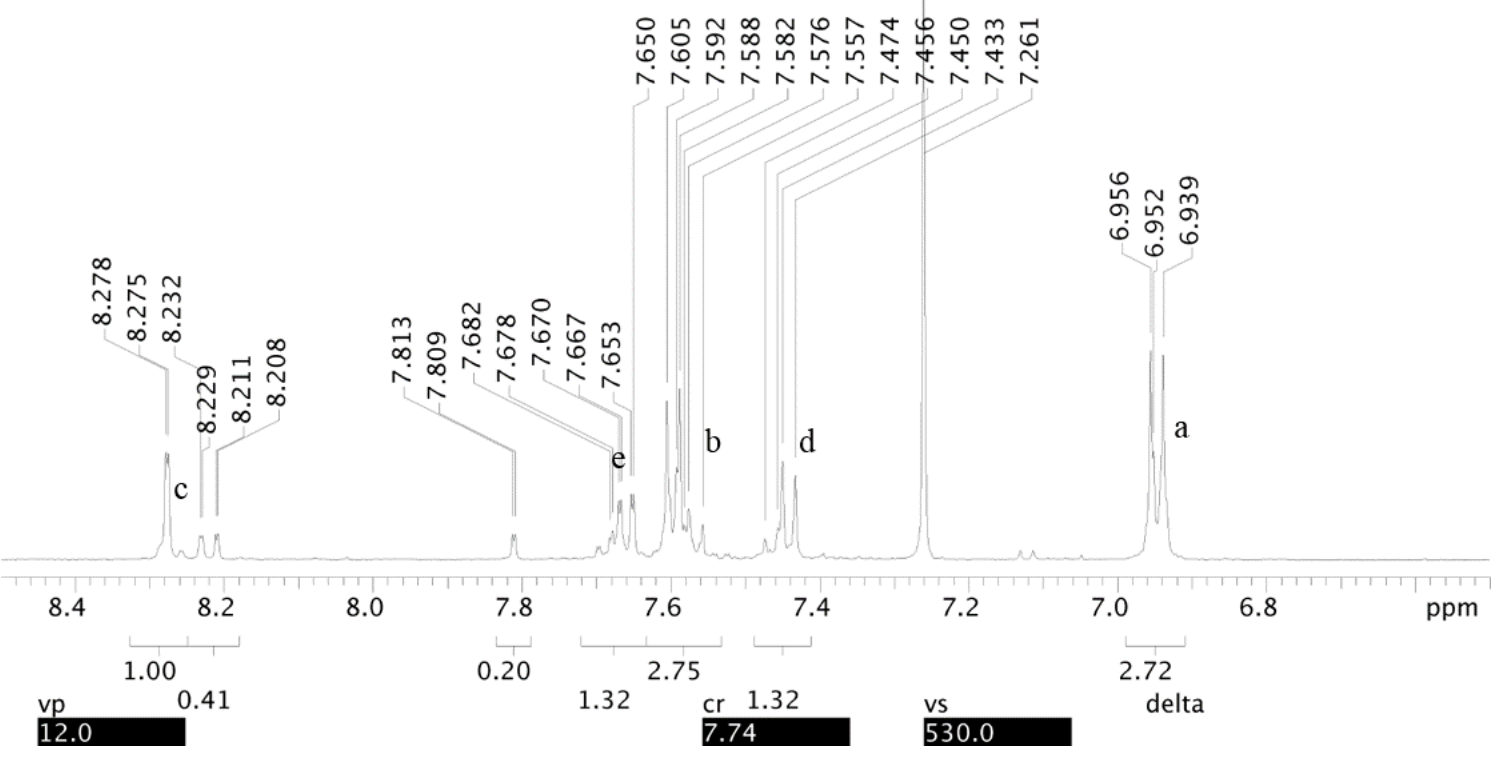

Figure S7. ${ }^{1} \mathrm{H}$ NMR spectrum of 4,4'-(9-hexyl-9H-carbazole-3,6-diyl)diphenol (Cz) from $6.5 \mathrm{ppm}$ to $8.5 \mathrm{ppm}$. 


\section{$m / z 200-1000$}

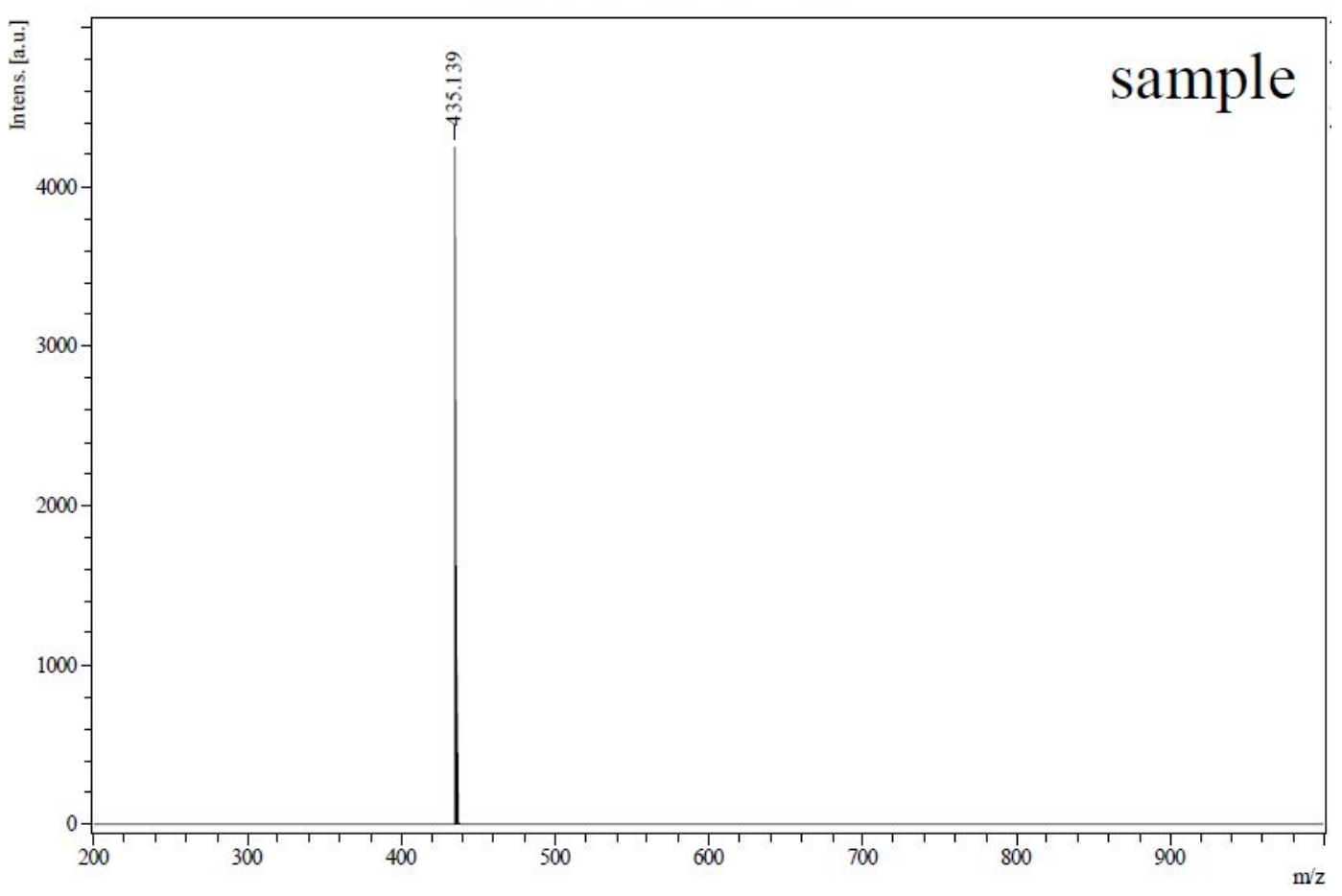

Figure S8. MALDI-TOF spectrum of 4,4'-(9-hexyl-9H-carbazole-3,6-diyl)diphenol (Cz) from 200 to 1000 $\mathrm{m} / \mathrm{z}$.

\section{$m / z 432-441$}

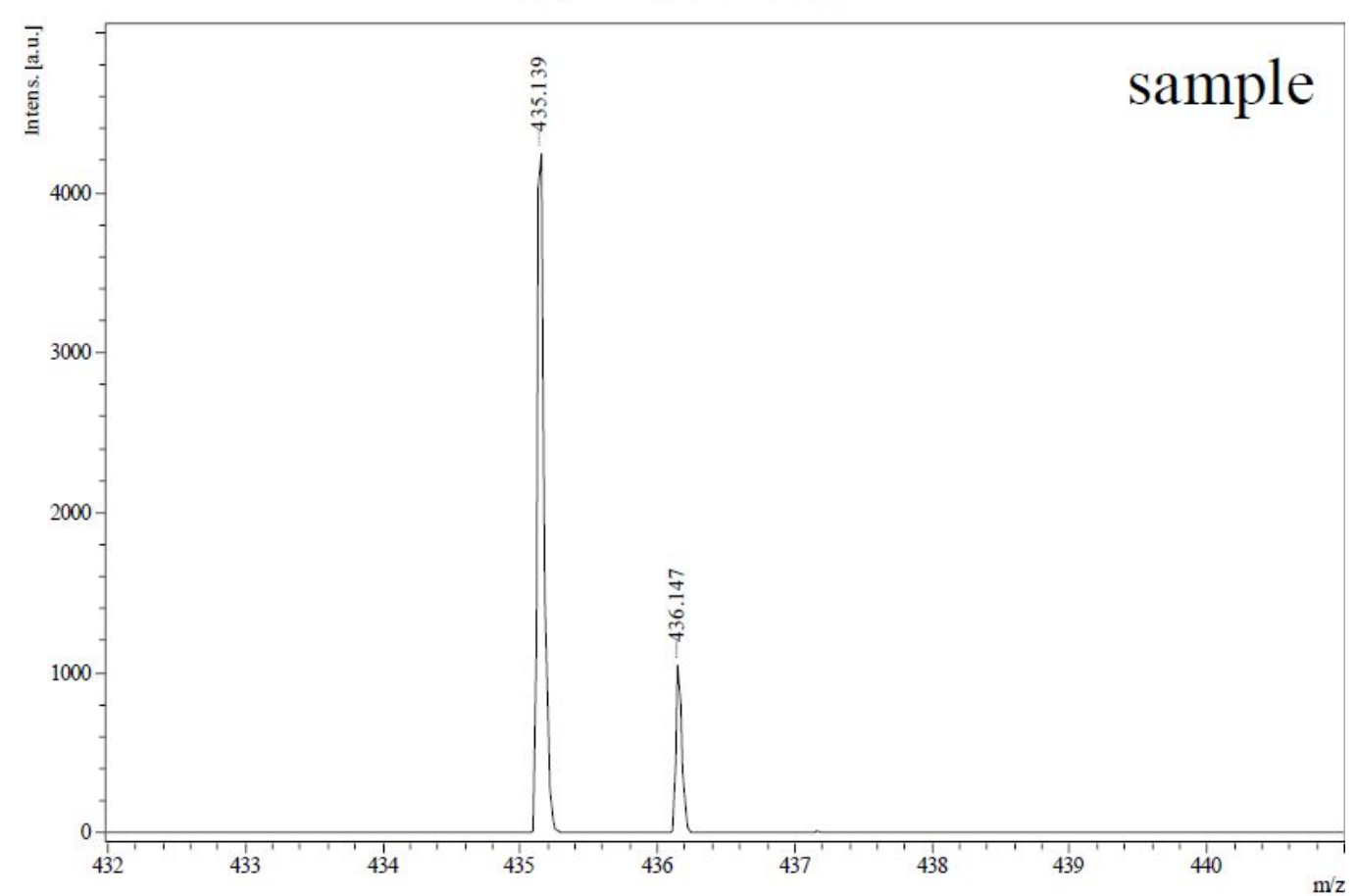

Figure S9. MALDI-TOF amplification spectrum of 4,4'-(9-hexyl-9H-carbazole-3,6-diyl)diphenol (Cz) from 432 to $441 \mathrm{~m} / \mathrm{z}$. 


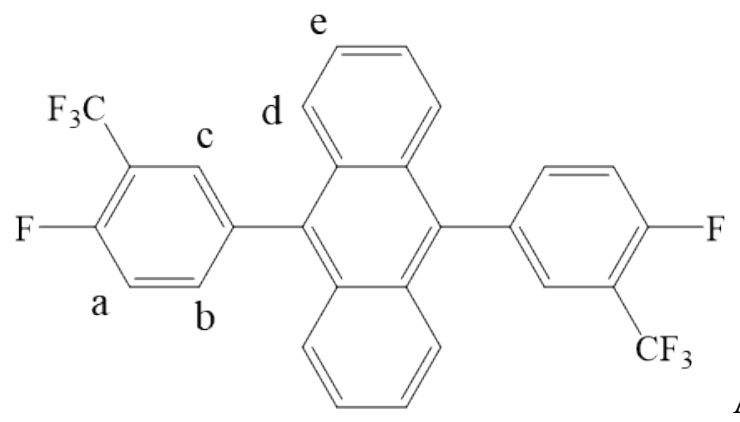

An

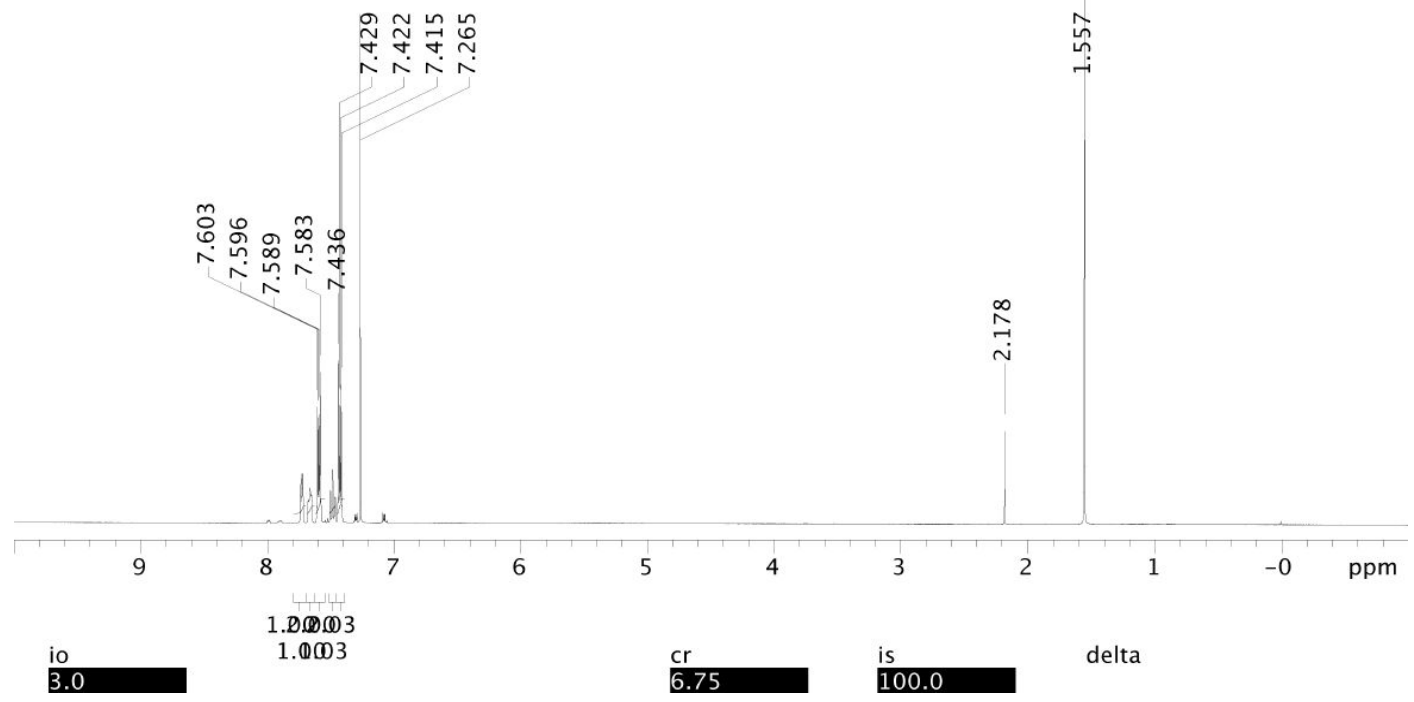

Figure S10. ${ }^{1} \mathrm{H}$ NMR spectrum of 9,10-bis(4-fluoro-3-(trifluoromethyl)phenyl)anthracene (An) from $0 \mathrm{ppm}$ to $10 \mathrm{ppm}$.

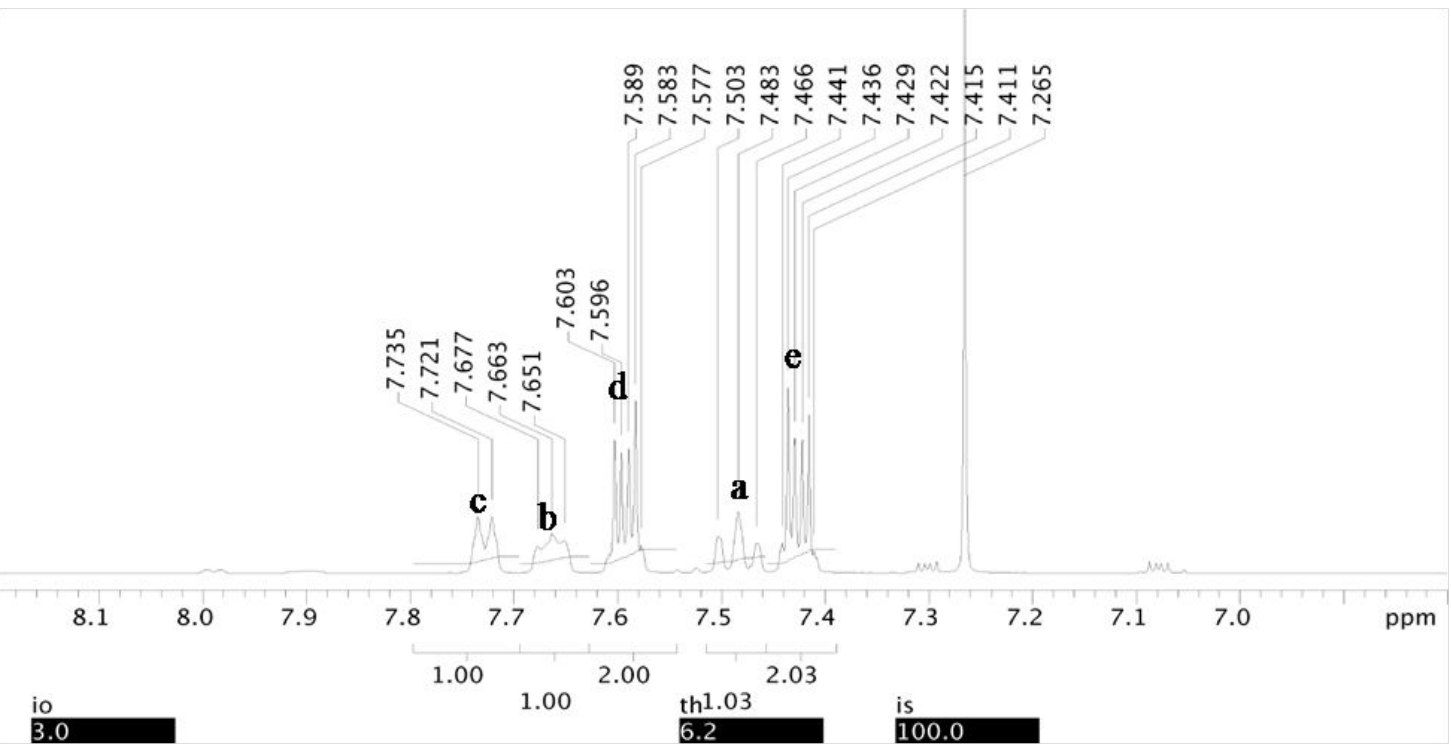

Figure S11. ${ }^{1} \mathrm{H}$ NMR spectrum of 9,10-bis(4-fluoro-3-(trifluoromethyl)phenyl)anthracene (An) from $6.8 \mathrm{ppm}$ to $8.2 \mathrm{ppm}$. 


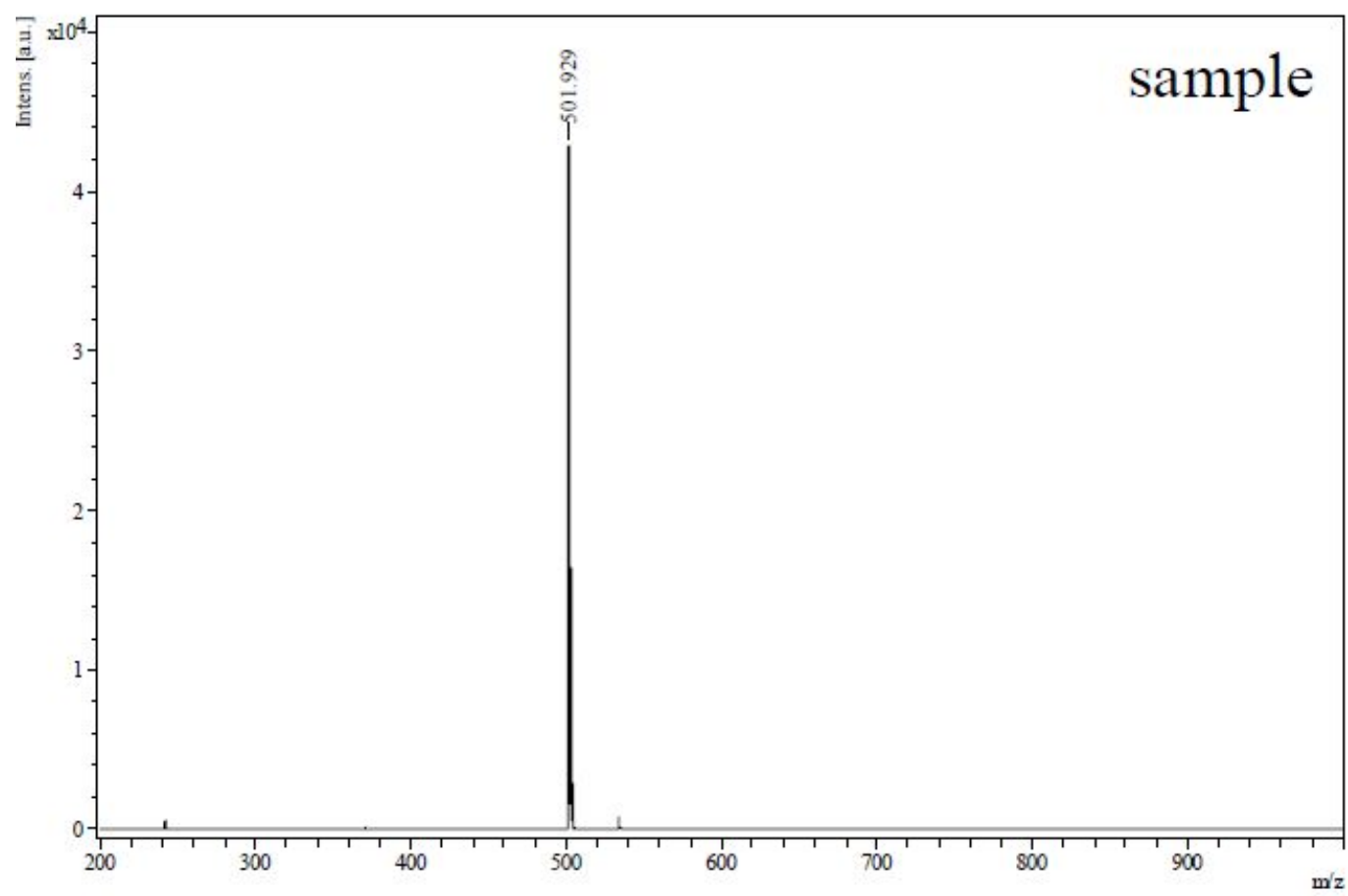

Figure S12. MALDI-TOF spectrum of 9,10-bis(4-fluoro-3-(trifluoromethyl)phenyl)anthracene (An) from 200 to $1000 \mathrm{~m} / \mathrm{z}$.

\section{$\mathrm{m} / z$ 495-510}

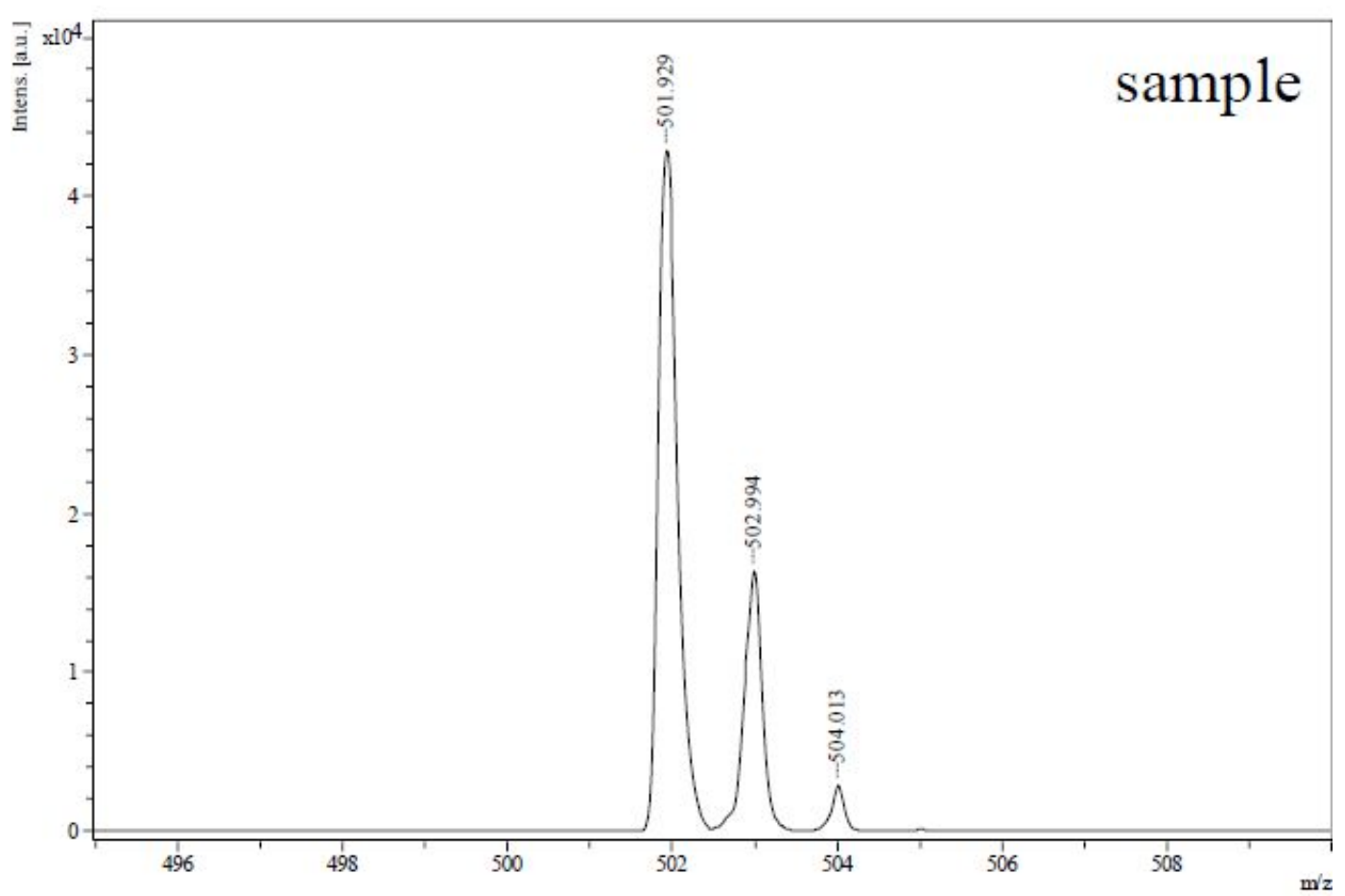

Figure S13. MALDI-TOF spectrum of 9,10-bis(4-fluoro-3-(trifluoromethyl)phenyl)anthracene (An) from 495 to $510 \mathrm{~m} / \mathrm{z}$. 

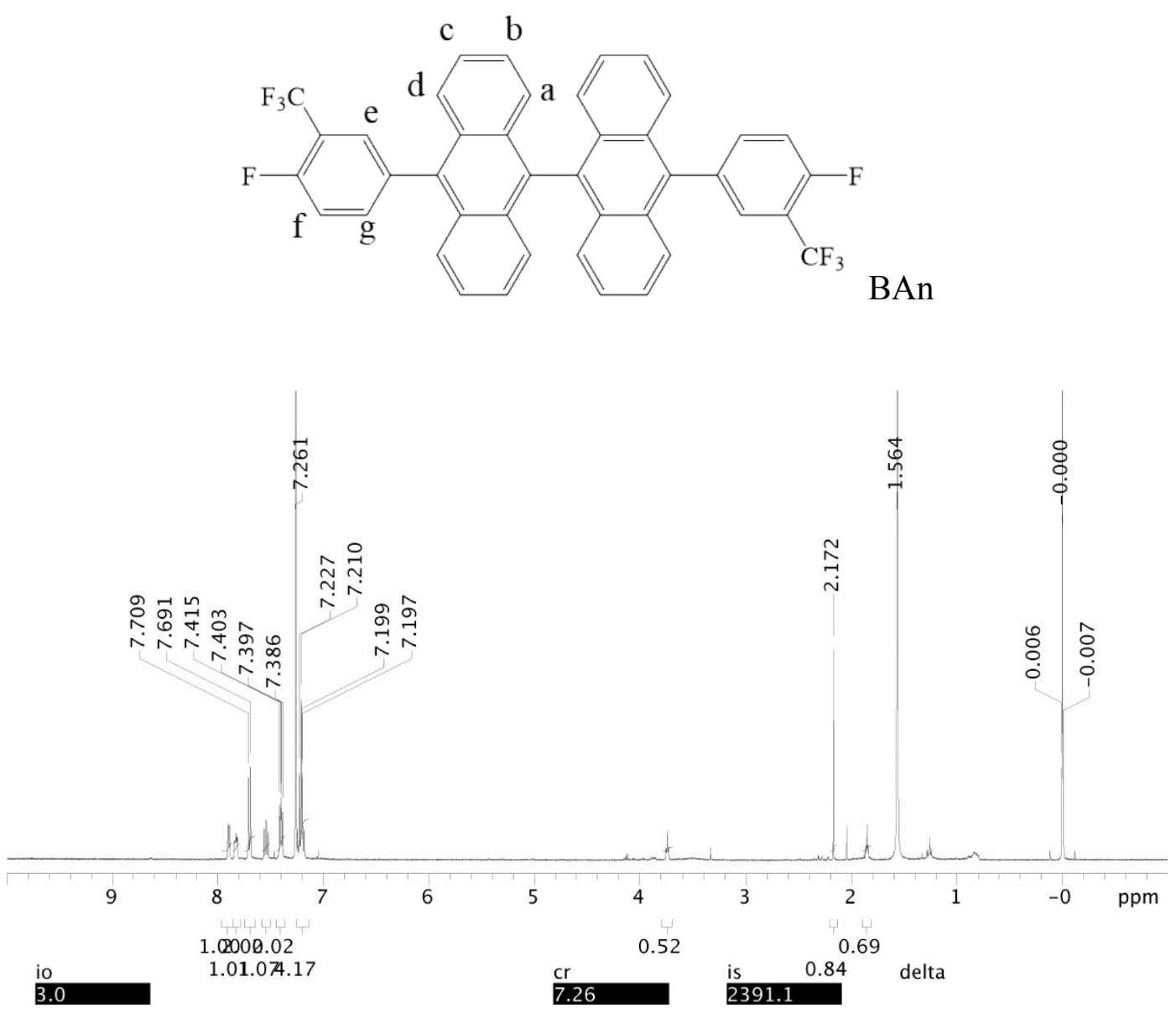

Figure S14. ${ }^{1} \mathrm{H}$ NMR spectrum of 10,10'-bis(4-fluoro-3-(trifluoromethyl)phenyl)-9,9'-bianthracene (BAn) from 0 ppm to $10 \mathrm{ppm}$.

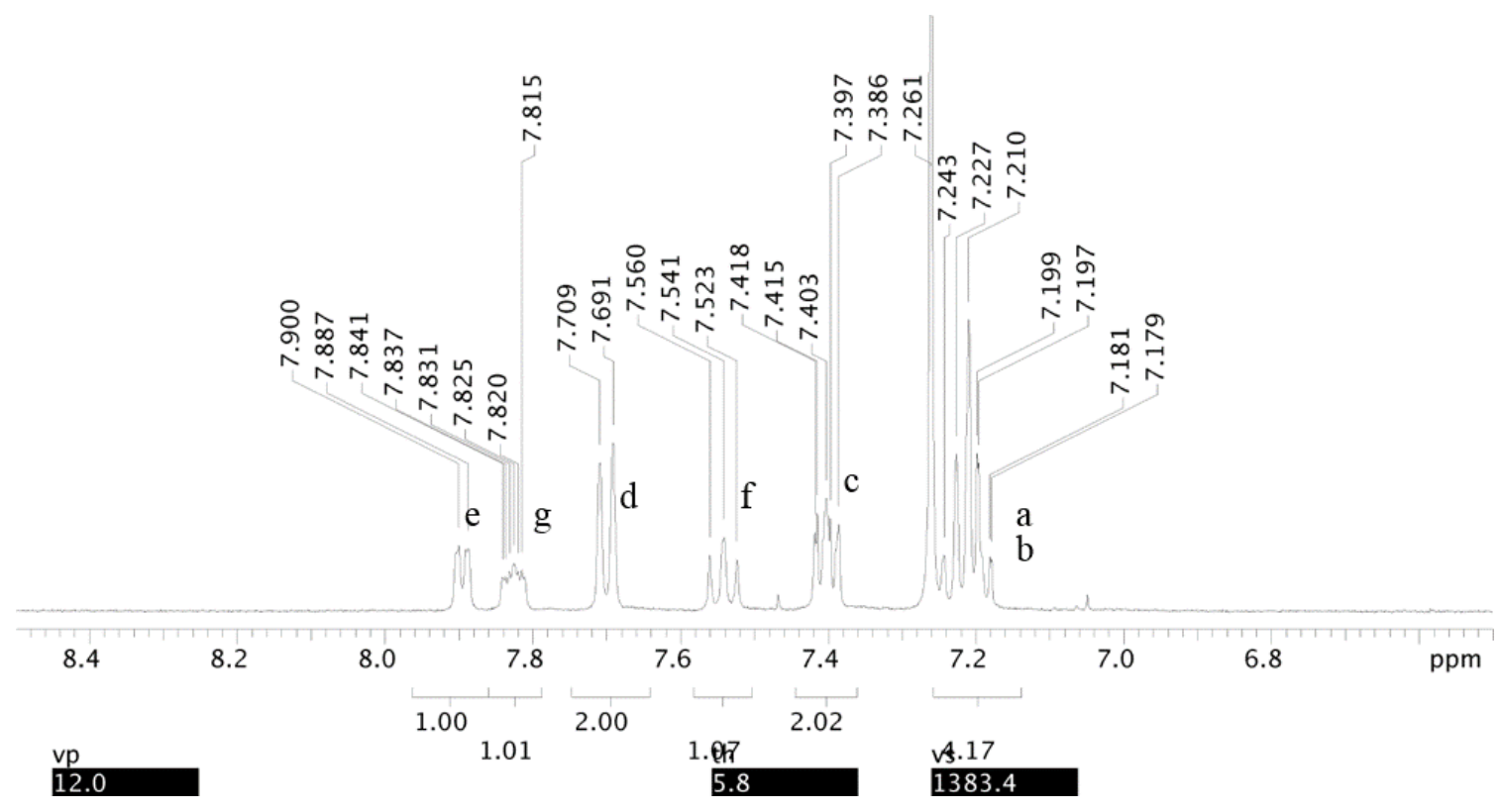

Figure S15. ${ }^{1} \mathrm{H}$ NMR spectrum of 10,10'-bis(4-fluoro-3-(trifluoromethyl)phenyl)-9,9'-bianthracene (BAn) from $6.6 \mathrm{ppm}$ to $8.5 \mathrm{ppm}$. 
$m / z 200-1000$

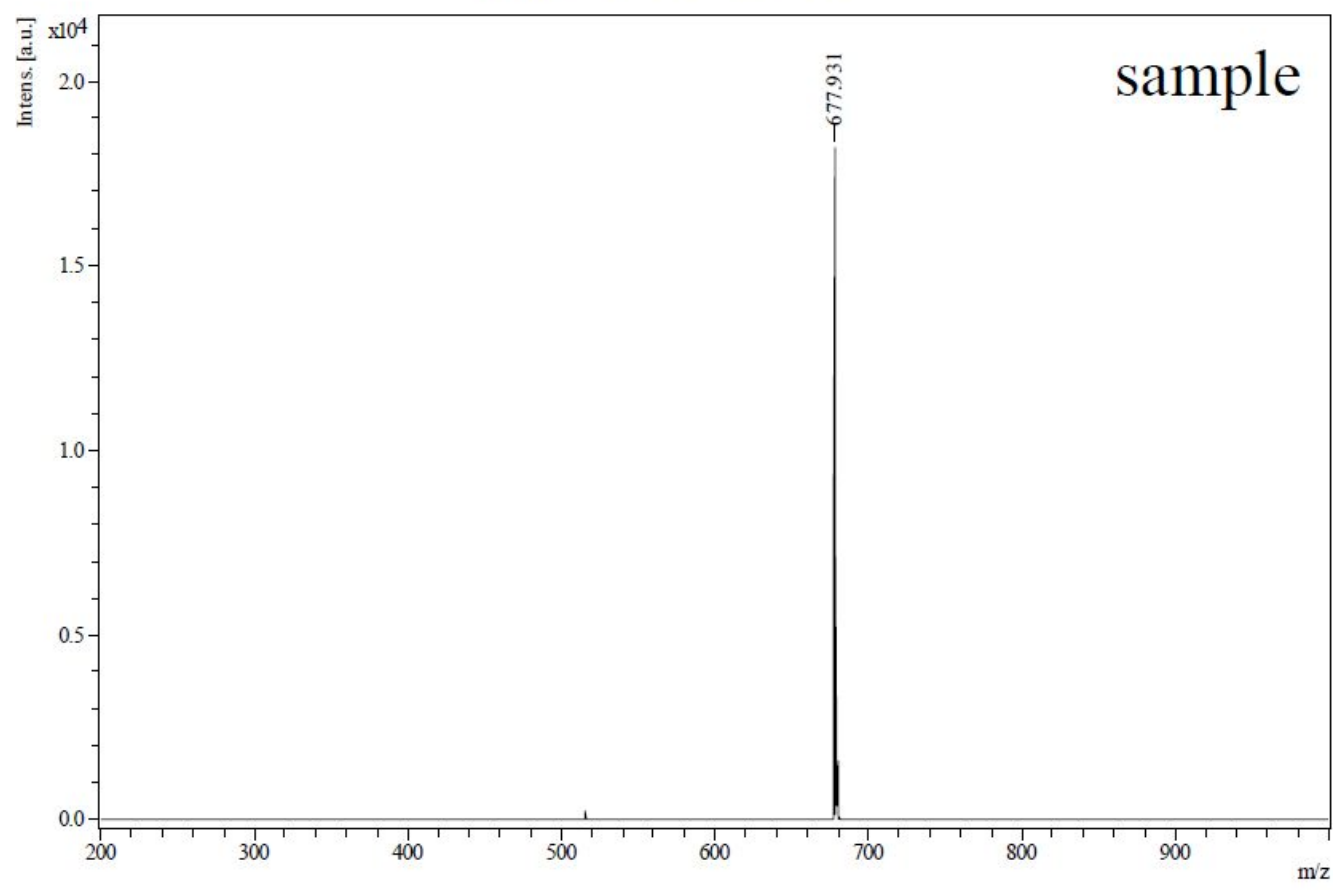

Figure S16. MALDI-TOF spectrum of 10,10'-bis(4-fluoro-3-(trifluoromethyl)phenyl)-9,9'-bianthracene (BAn) from 495 to $510 \mathrm{~m} / \mathrm{z}$.

\section{$m / z 673-685$}

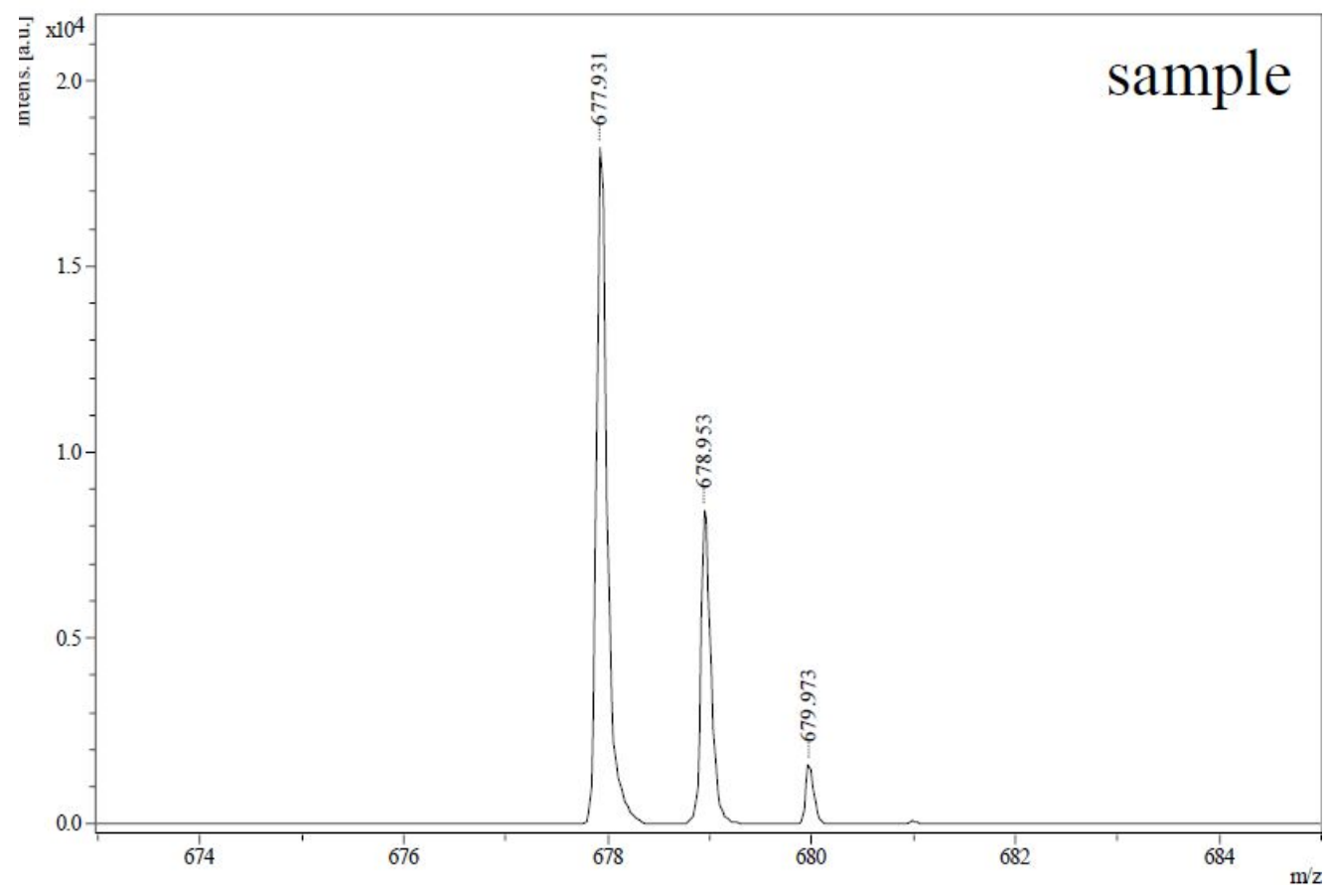

Figure S17. MALDI-TOF spectrum of 10,10'-bis(4-fluoro-3-(trifluoromethyl)phenyl)-9,9'-bianthracene (BAn) from 673 to $685 \mathrm{~m} / \mathrm{z}$. 

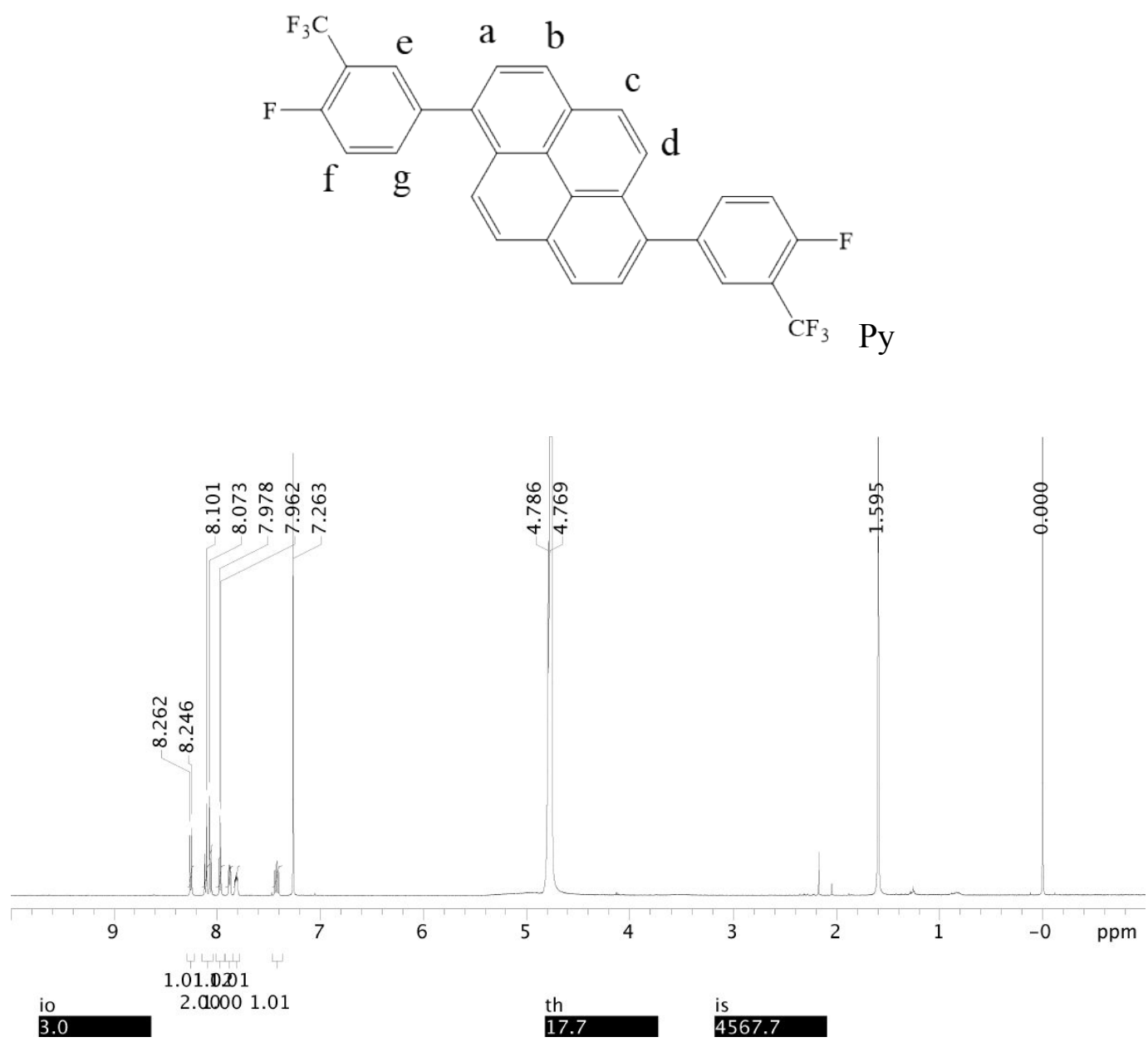

Figure S18. ${ }^{1} \mathrm{H}$ NMR spectrum of 1,6-bis(4-fluoro-3-(trifluoromethyl)phenyl)pyrene (Py) from 0 ppm to 10 ppm.

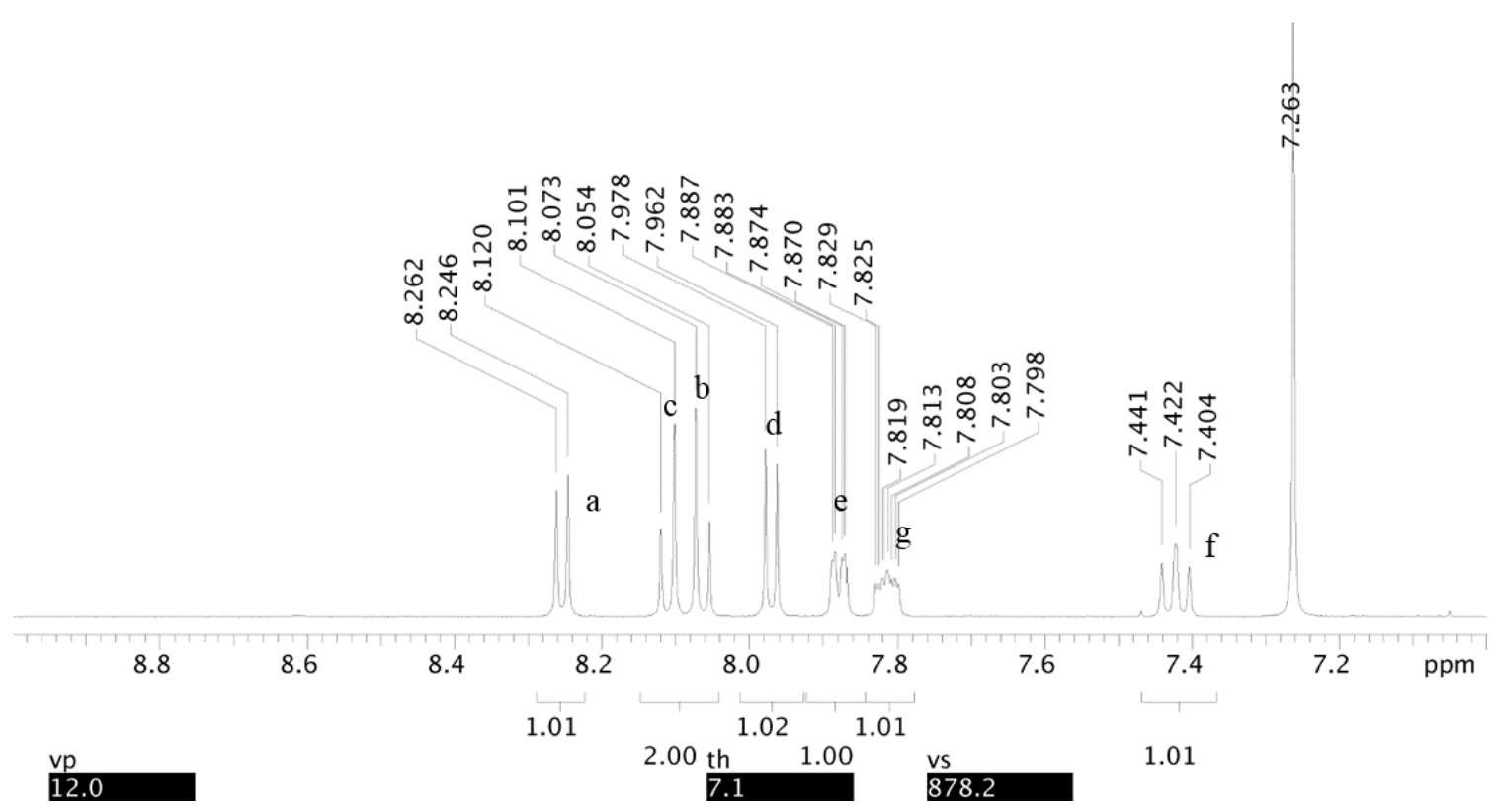

Figure S19. ${ }^{1} \mathrm{H}$ NMR spectrum of 1,6-bis(4-fluoro-3-(trifluoromethyl)phenyl)pyrene (Py) from $7.0 \mathrm{ppm}$ to $9.0 \mathrm{ppm}$. 
$m / z 200-1000$

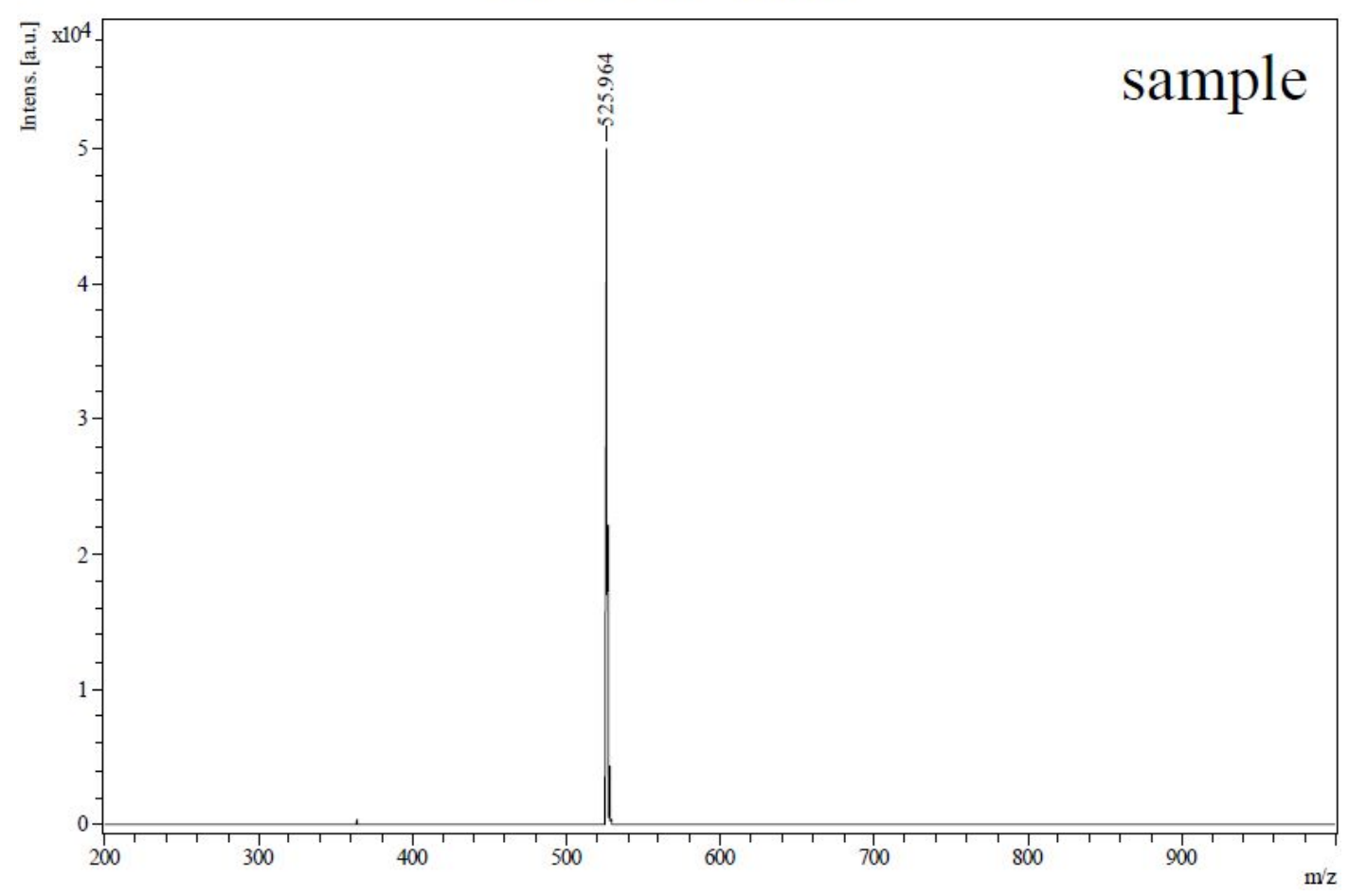

Figure S20. MALDI-TOF spectrum of 1,6-bis(4-fluoro-3-(trifluoromethyl)phenyl)pyrene (Py) from 200 to $1000 \mathrm{~m} / \mathrm{z}$

\section{$m / z 522-532$}

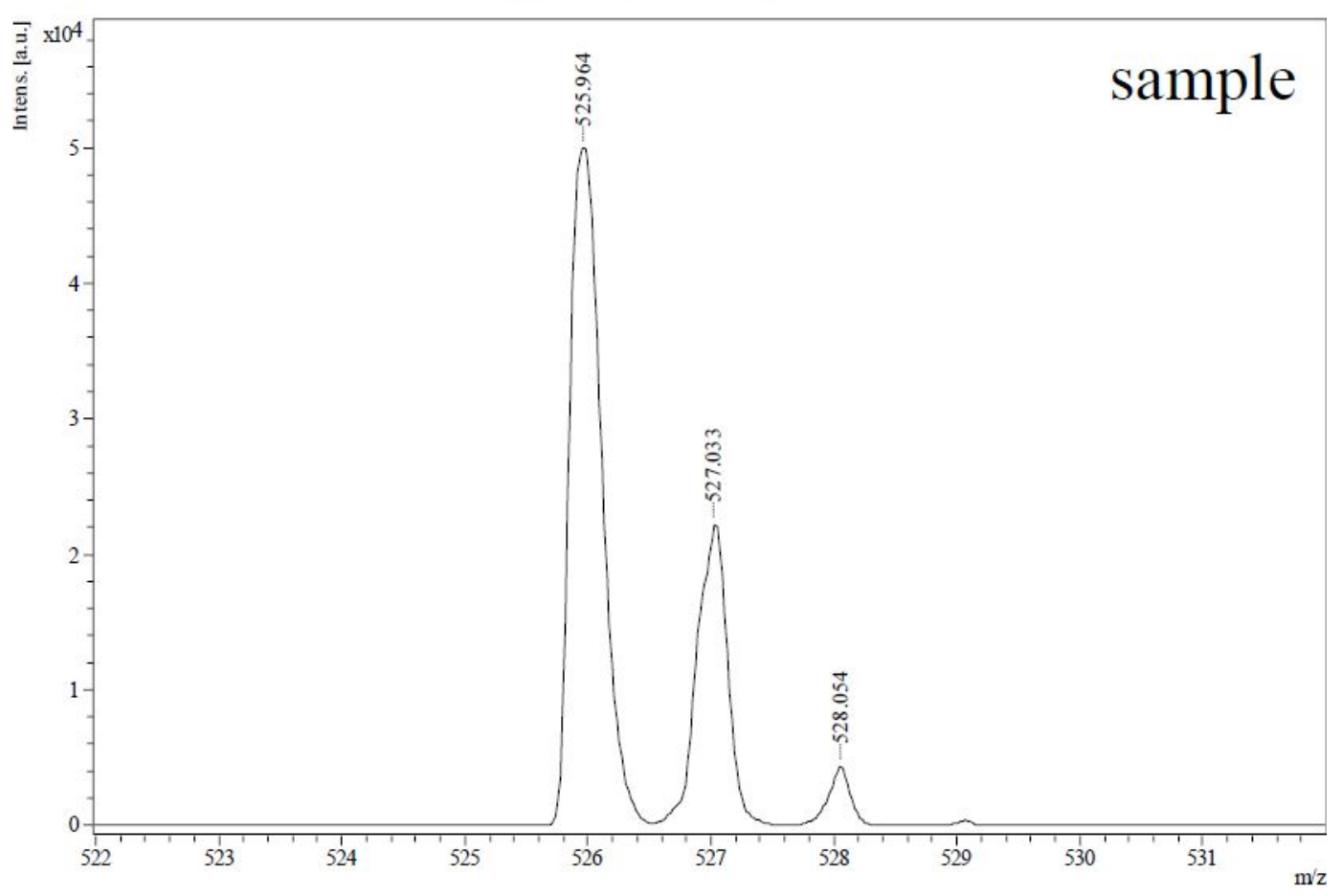

Figure S21. MALDI-TOF spectrum of 1,6-bis(4-fluoro-3-(trifluoromethyl)phenyl)pyrene (Py) from 525 to $532 \mathrm{~m} / \mathrm{z}$. 


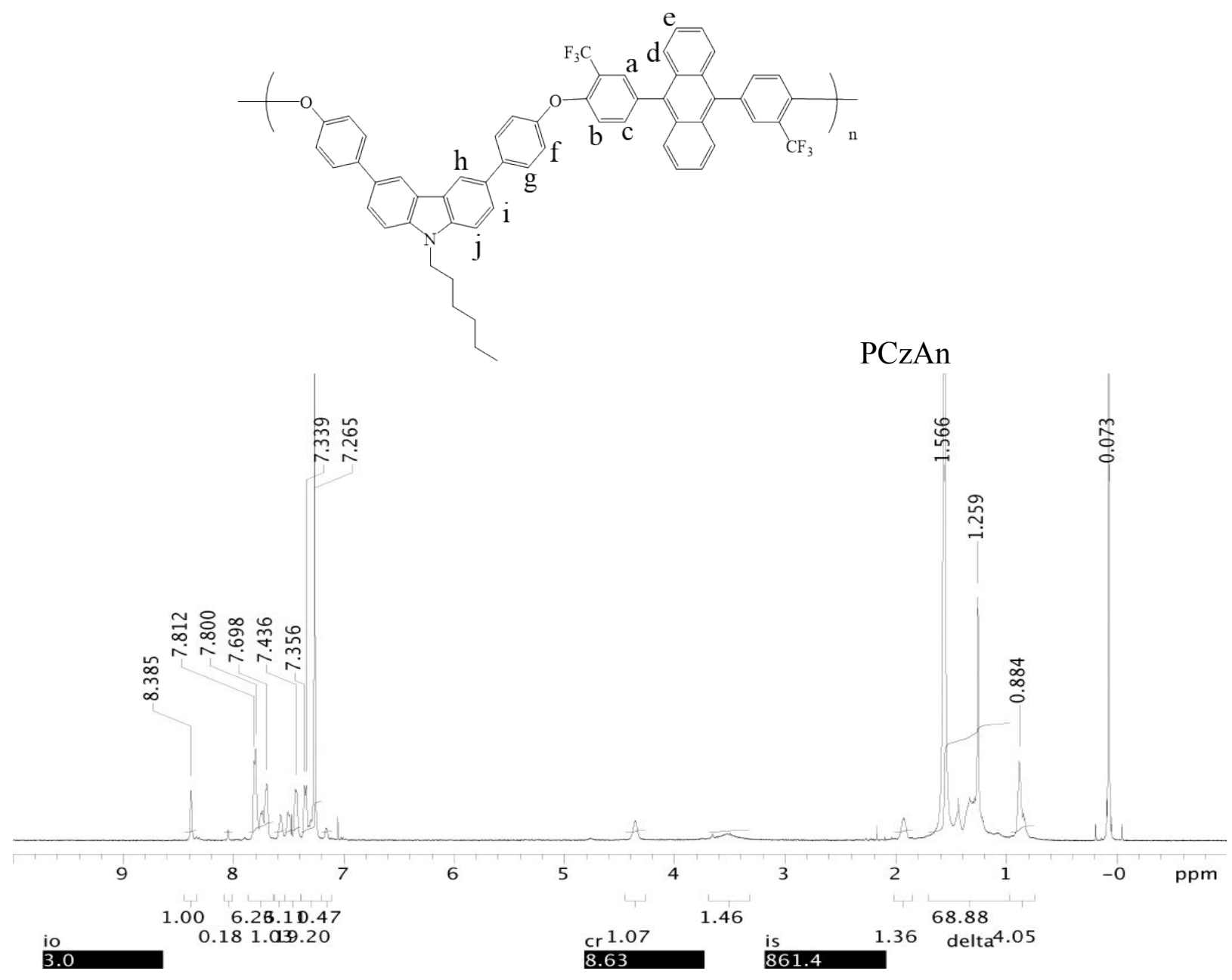

Figure S22. ${ }^{1} \mathrm{H}$ NMR spectrum of PCzAn from $0 \mathrm{ppm}$ to $10 \mathrm{ppm}$.

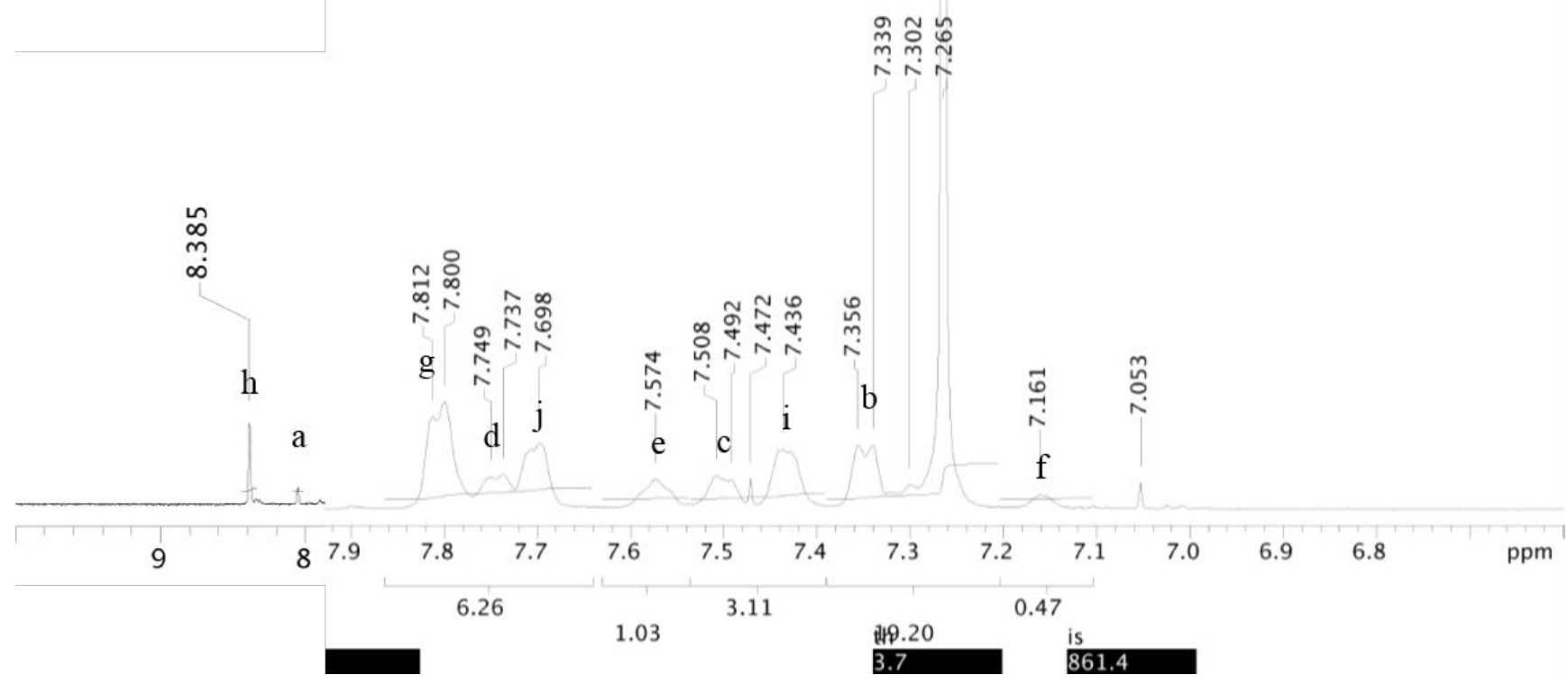

Figure S23. ${ }^{1} \mathrm{H}$ NMR spectrum of PCzAn from $6.6 \mathrm{ppm}$ to $10 \mathrm{ppm}$. 


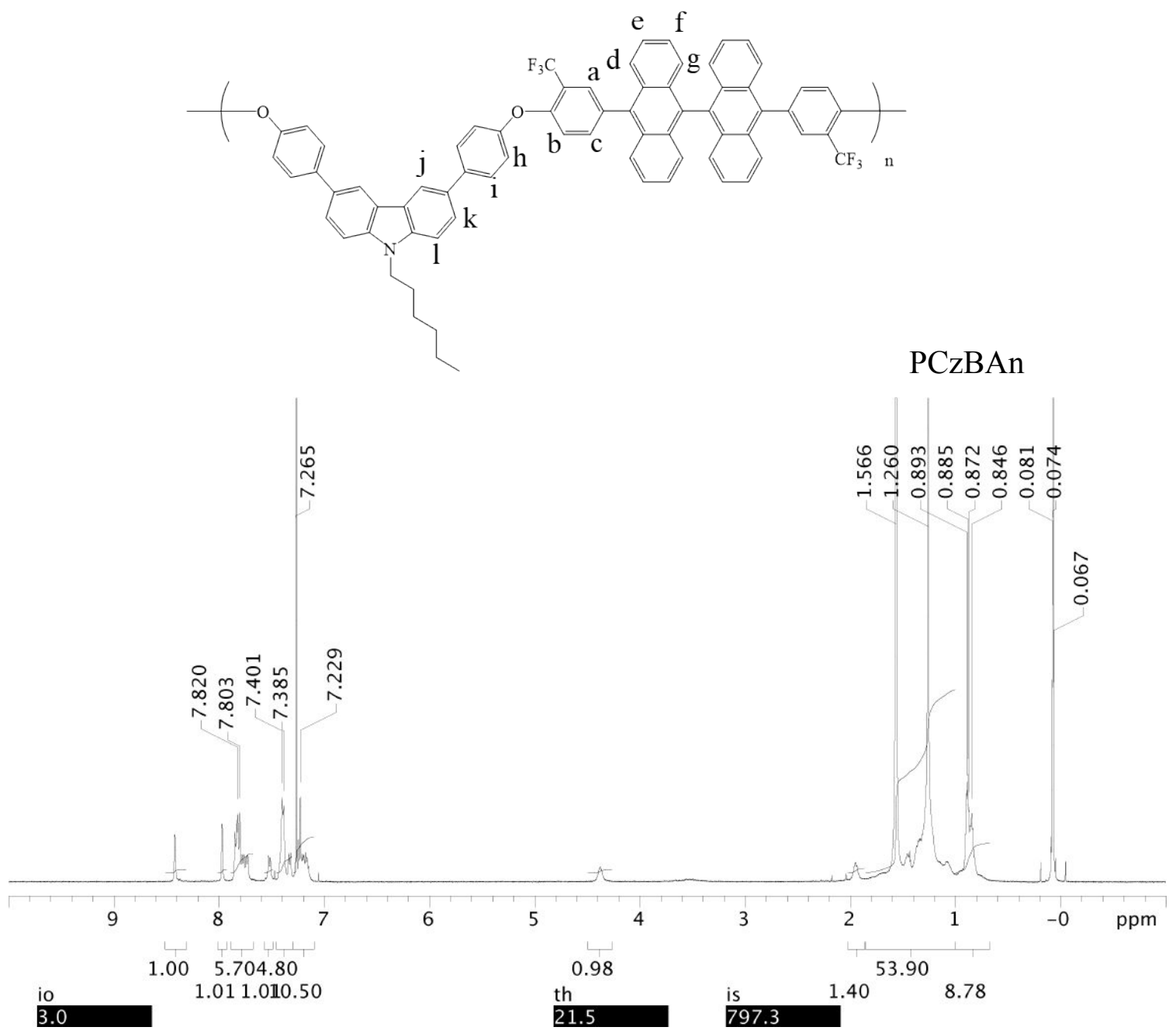

Figure S24. ${ }^{1} \mathrm{H}$ NMR spectrum of PCzBAn from $0 \mathrm{ppm}$ to $10 \mathrm{ppm}$.

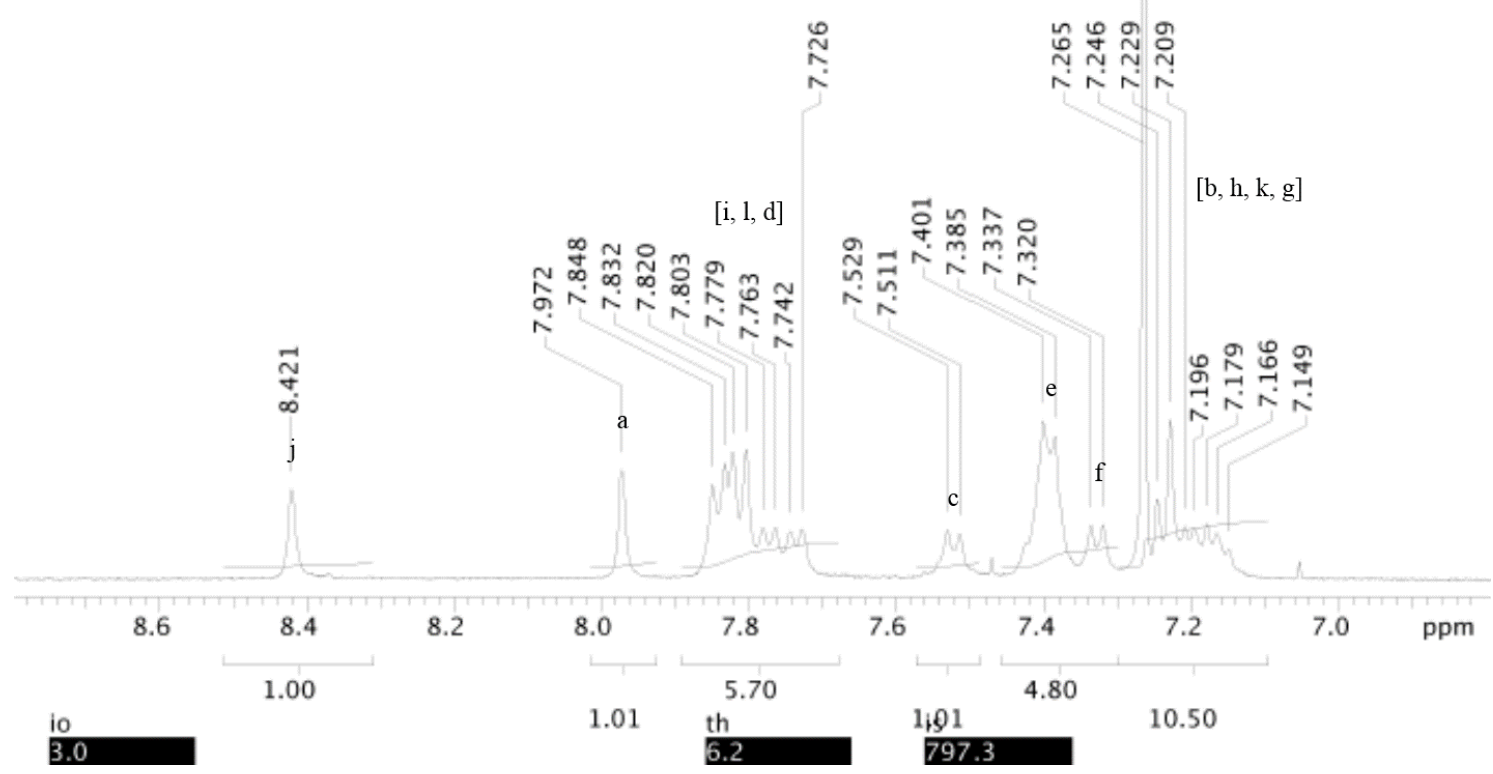

Figure S25. ${ }^{1} \mathrm{H}$ NMR spectrum of PCzBAn from $6.8 \mathrm{ppm}$ to $8.8 \mathrm{ppm}$. 

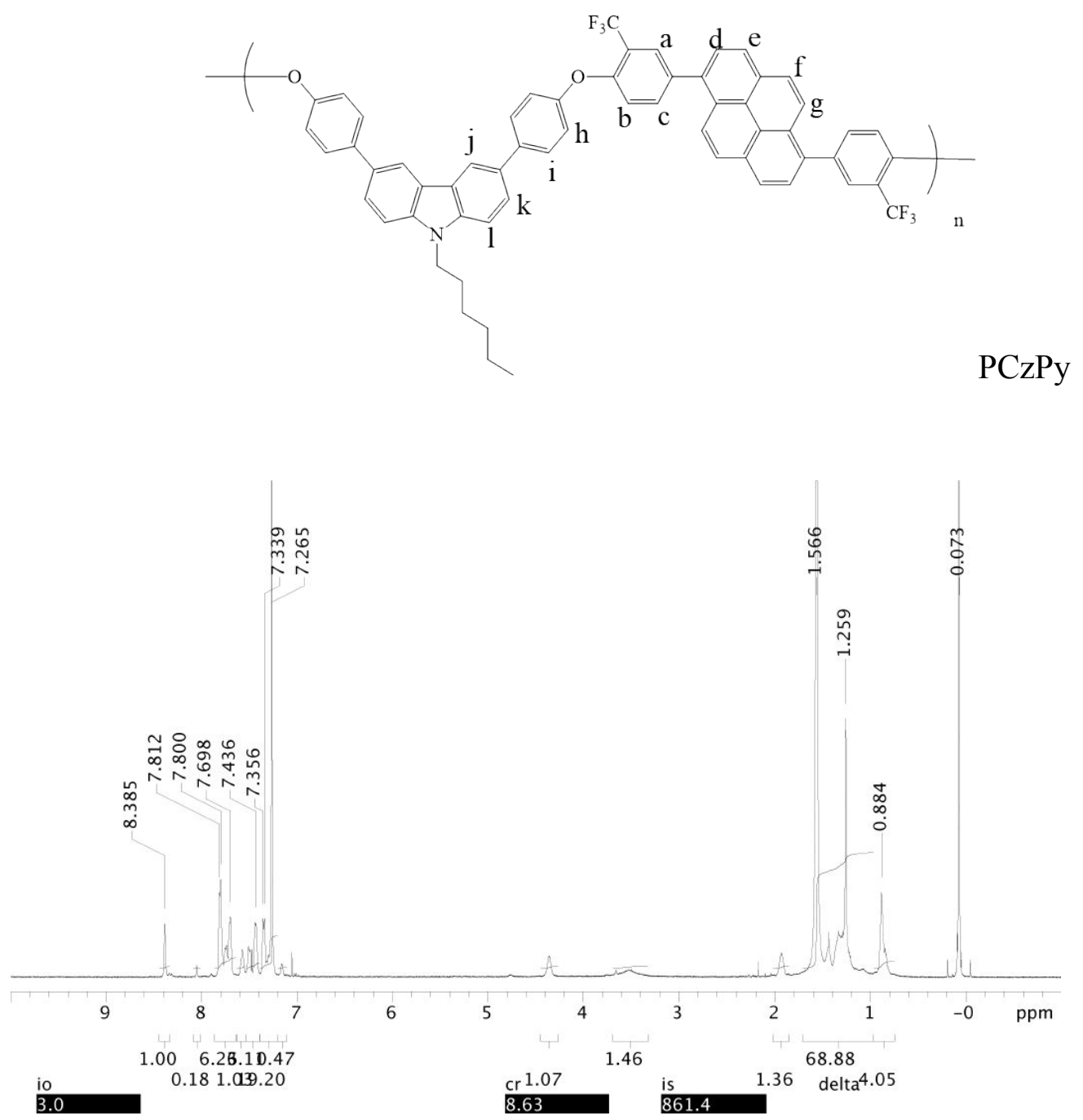

Figure S26. ${ }^{1} \mathrm{H}$ NMR spectrum of $\mathrm{PCzPy}$ from $0 \mathrm{ppm}$ to $10 \mathrm{ppm}$.

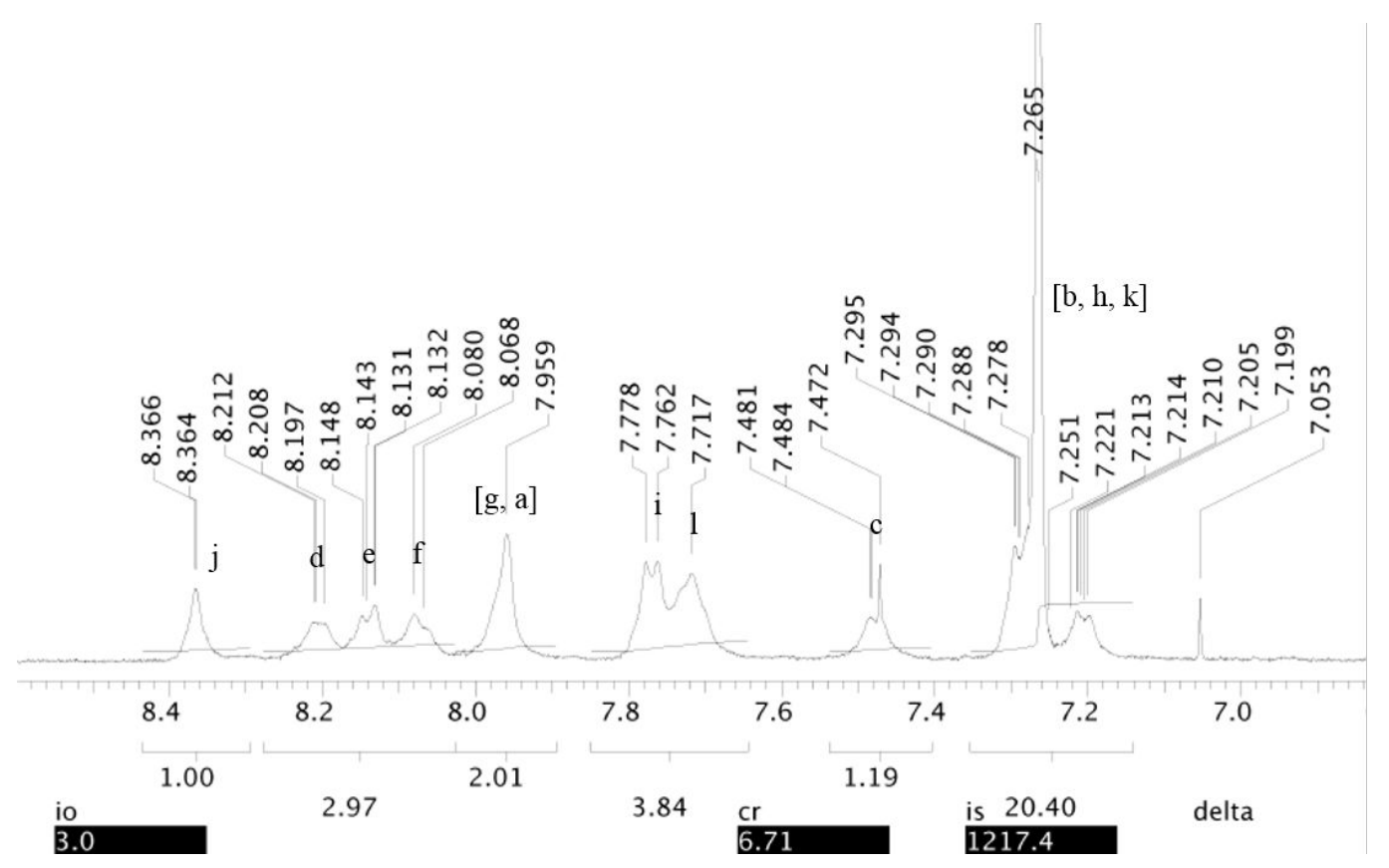

Figure S27. ${ }^{1} \mathrm{H}$ NMR spectrum of PCzPy from $6.8 \mathrm{ppm}$ to $8.6 \mathrm{ppm}$. 

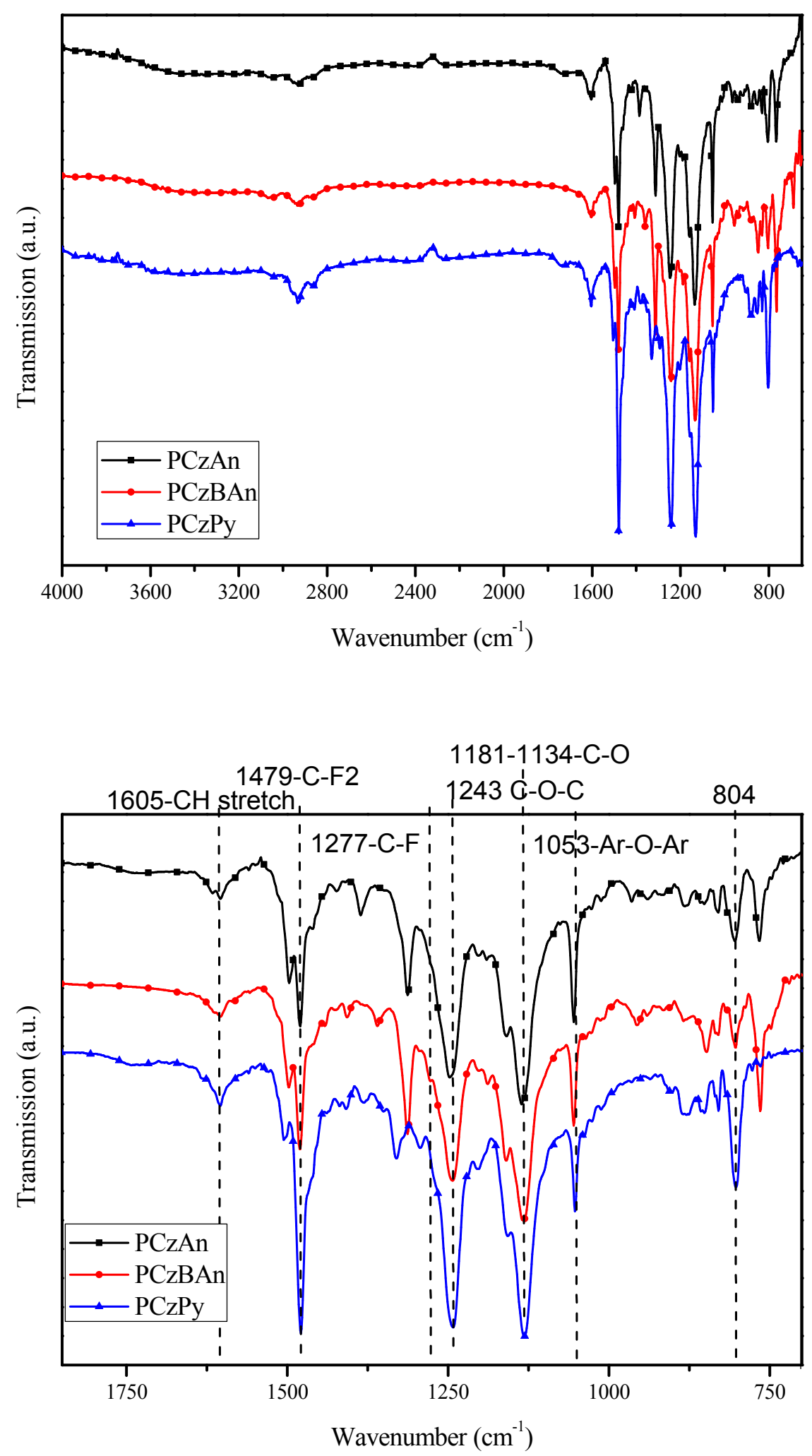

Figure S28. FTIR spectrum of three copolymers. 
The glass temperature of PCzAn, PCzBAn, and PCzPy was at 221, 230 and $221{ }^{\circ} \mathrm{C}$, respectively. That revealed that all polymers have excellent thermal stability.
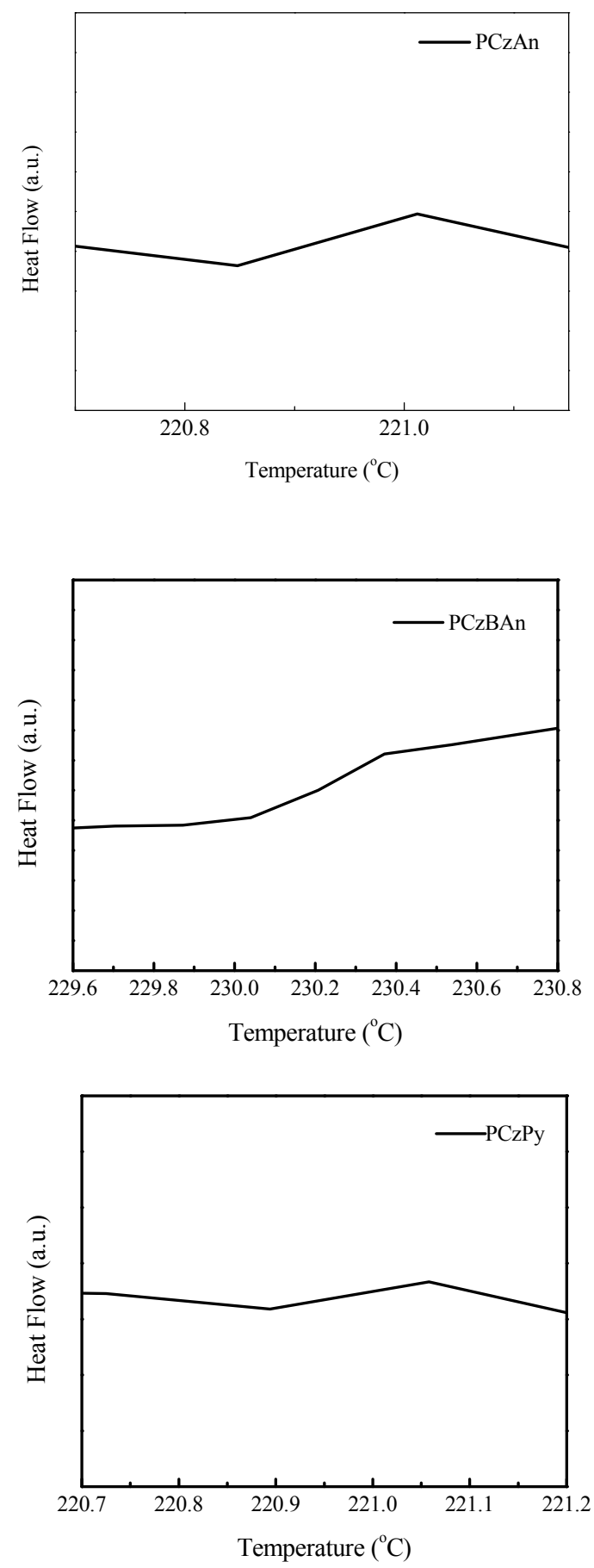

Figure S29. DSC curves of the polymers of PCzAn, PCzBAn and PCzPy 


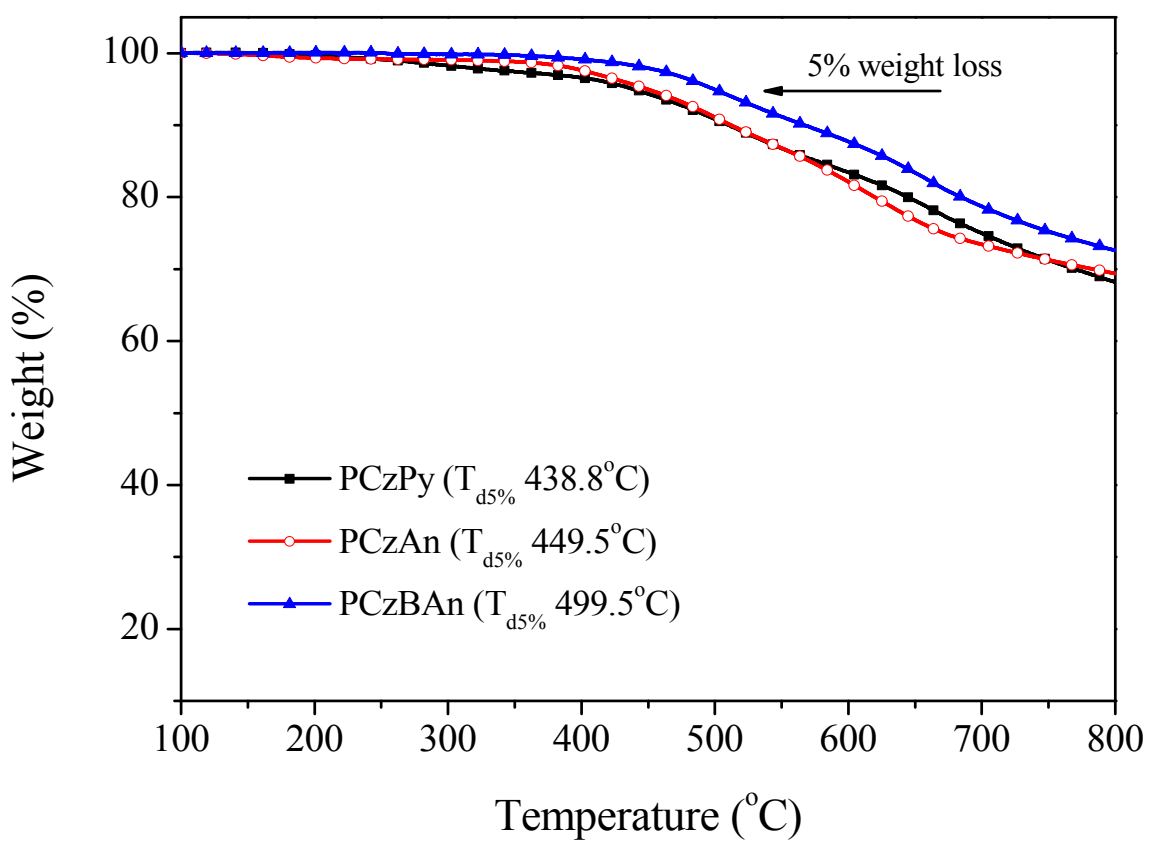

Figure S30. TGA curves of decomposed temperatures that correspond to a $5 \%$ weight loss in the process of upon heating within TGA measured are around $449.5,449.5$ and $438.8{ }^{\circ} \mathrm{C}$ of PCzAn, PCzBAn, and PCzPy respectively. 


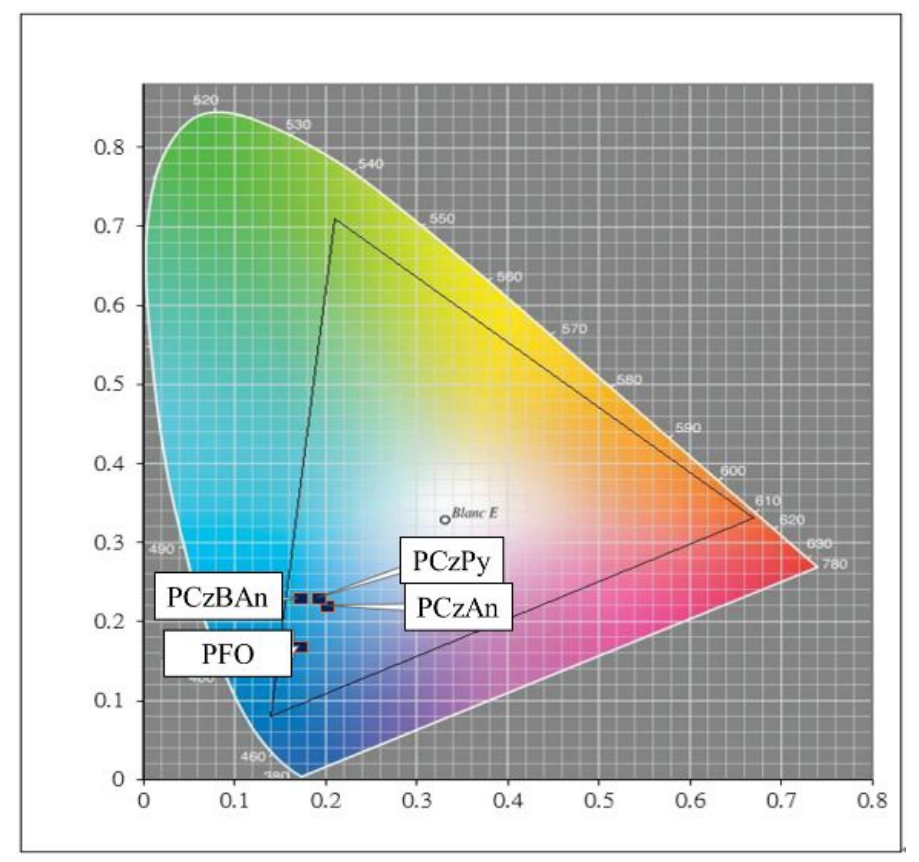

Figure S31. CIE Coordinates of PCzAn, PCzBAn, PCzPy or PFO as emitting layer non-doped device.

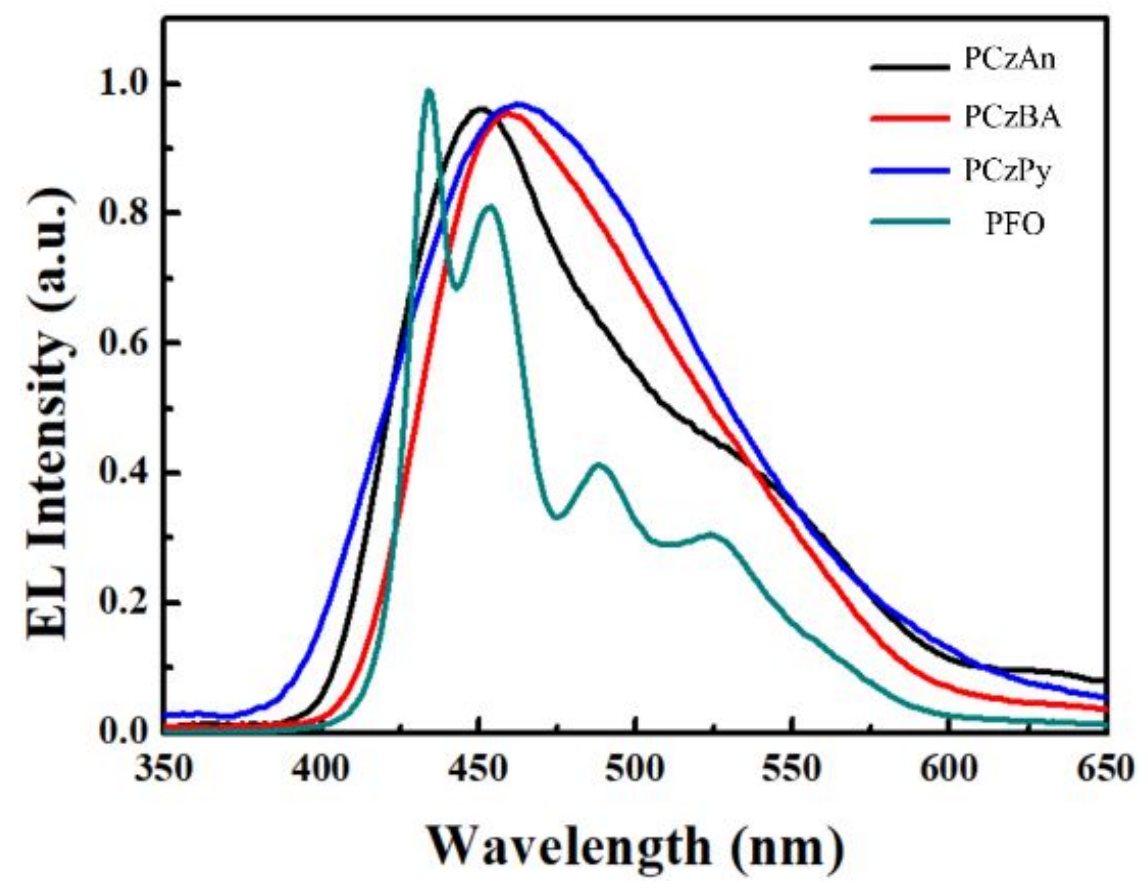

Figure S32. Electroluminescence spectra of PCzAn, PCzBAn, PCzPy or PFO as emitting layer non-doped device. 
Table S1. Quantum yield of polymers at $10^{-3} \mathrm{M}$ in Chlorobenzene

\begin{tabular}{ccccc}
\hline Polymer & PFO & PCzAn & PCzBAn & PCzPy \\
\hline Q.Y. ${ }^{\text {a }}$ & 0.60 & 0.70 & 0.73 & 0.38 \\
\hline
\end{tabular}

a Relative photoluminescence quantum yield of polymers was measured by the absorption spectrum and the emission spectrum of the solution state

Table S2. Molecular weights and thermal properties of polymers

\begin{tabular}{lccccc}
\hline Polymer & $\mathbf{M}_{\mathbf{w}}{ }^{\mathbf{a}}(\mathbf{k D a})$ & $\left.\mathbf{M}_{\mathbf{n}}{ }^{\mathbf{a}} \mathbf{( k D a}\right)$ & $\mathbf{P D I}$ & $\mathbf{T}_{\mathbf{g}}\left({ }^{\circ} \mathbf{C}\right)$ & $\mathbf{T}_{\mathbf{d 5} \%}{ }^{\mathbf{b}}\left({ }^{\circ} \mathbf{C}\right)$ \\
\hline PCzAn & 80.0 & 17.8 & 4.5 & 221 & 449.5 \\
PCzBAn & 133 & 33.3 & 4.0 & 230 & 499.5 \\
PCzPy & 128 & 35.6 & 3.6 & 221 & 438.8 \\
\hline
\end{tabular}

${ }^{a}$ Molecular weights were determined by GPC, eluting with THF, by comparison with polystyrene standards.

${ }^{\mathrm{b}}$ Temperature at which a $5 \%$ weight loss occurred was determined at a heating rate of $10{ }^{\circ} \mathrm{C} / \mathrm{min}$ under a nitrogen atmosphere

Table S3. The characteristics of non-doped electroluminescent devices using coated process.

\begin{tabular}{|c|c|c|c|c|c|}
\hline Polymer & $\begin{array}{l}V_{\text {on }^{a}} \\
(\mathrm{~V})\end{array}$ & $\begin{array}{c}\text { Luminance }_{\max }{ }^{b} \\
\left(\mathbf{c d} / \mathbf{m}^{2}\right)\end{array}$ & $\begin{array}{l}\mathbf{L E}_{\max }{ }^{\mathrm{c}} \\
(\mathrm{cd} / \mathrm{A})\end{array}$ & $\begin{array}{c}\mathrm{EQE}_{\max }^{\mathrm{d}} \\
(\%)\end{array}$ & $\begin{array}{l}\text { CIE }^{\mathrm{e}} \\
(\mathrm{x}, \mathrm{y})\end{array}$ \\
\hline PCzAn & 7.0 & 37 & 0.03 & 0.08 & $0.20,0.22$ \\
\hline PCzBAn & 8.2 & 50 & 0.23 & 0.14 & $0.17,0.23$ \\
\hline $\mathrm{PCzPy}$ & 6.0 & 12 & 0.01 & 0.01 & $0.19,0.23$ \\
\hline PFO & 6.8 & 239 & 0.11 & 0.06 & $0.17,0.17$ \\
\hline
\end{tabular}

aturn-on voltage

${ }^{\mathrm{b}}$ maximum luminance

${ }^{c}$ maximum current efficiency

${ }^{d}$ maximum external quantum efficiency

${ }^{\mathrm{e} C o m m i s s i o n}$ Internationale de l'Éclairage 
Table S4. EL devices with structure of ITO $(120 \mathrm{~nm}) /$ PEDOT: PSS (50 nm)/emitting polymers (PCzBAn: PFO) $(45 \mathrm{~nm}) /$ TPBi $(35 \mathrm{~nm}) / \mathrm{LiF}(1 \mathrm{~nm}) / \mathrm{Al}(150 \mathrm{~nm})$ (a) voltagecurrent density and (b) luminance-voltage curves

\begin{tabular}{|c|c|c|c|c|c|}
\hline $\begin{array}{c}\text { Polymer ratio of } \\
\text { PCzBAn:PFO } \\
\text { (wt\%) }\end{array}$ & $\begin{array}{l}V_{\text {on }^{\mathrm{a}}} \\
(\mathrm{V})\end{array}$ & $\begin{array}{c}\text { Luminance }_{\max }{ }^{b} \\
\left(\mathbf{c d} / \mathbf{m}^{2}\right)\end{array}$ & $\begin{array}{l}\mathbf{L E} \mathbf{E}_{\max }{ }^{\mathrm{c}} \\
(\mathrm{cd} / \mathrm{A})\end{array}$ & $\begin{array}{c}\mathrm{EQE}_{\max }{ }^{\mathrm{d}} \\
(\%)\end{array}$ & $\begin{array}{l}\mathrm{CIE}^{\mathrm{e}} \\
(\mathbf{x , y})\end{array}$ \\
\hline $0: 1$ & 3.5 & 1281 & 0.38 & 0.21 & $0.17,0.25$ \\
\hline $5: 5$ & 5 & 1133 & 0.9 & 0.52 & $0.17,0.23$ \\
\hline $8: 2$ & 5 & 898 & 2.44 & 1.67 & $0.16,0.18$ \\
\hline $9: 1$ & 4.5 & 2030 & 1.1 & 0.65 & $0.17,0.22$ \\
\hline $9.5: 0.5$ & 5.5 & 954 & 2.5 & 1.4 & $0.17,0.22$ \\
\hline $1: 0$ & 8 & 941 & 1.69 & 0.98 & $0.17,0.23$ \\
\hline \multicolumn{6}{|l|}{ aturn-on voltage } \\
\hline \multicolumn{6}{|l|}{${ }^{\mathrm{b}}$ maximum luminance } \\
\hline \multicolumn{6}{|c|}{${ }^{c}$ maximum current efficiency } \\
\hline \multicolumn{6}{|c|}{${ }^{d}$ maximum external quantum efficiency } \\
\hline
\end{tabular}

Table S5. EL devices with structure of ITO $(120 \mathrm{~nm}) /$ PEDOT: PSS (50 nm)/emitting polymers (PCzBAn: PVK) $(45 \mathrm{~nm}) / \mathrm{TPBi}(35 \mathrm{~nm}) / \mathrm{LiF}(1 \mathrm{~nm}) / \mathrm{Al}(150 \mathrm{~nm})(a)$ voltagecurrent density and (b) luminance-voltage curves

\begin{tabular}{|c|c|c|c|c|c|}
\hline $\begin{array}{c}\text { Polymer ratio of } \\
\text { PCzBAn:PVK } \\
(w t \%)\end{array}$ & $\begin{array}{l}V_{\text {on }^{a}} \\
(\mathrm{~V})\end{array}$ & $\begin{array}{c}\text { Luminance }_{\max }{ }^{b} \\
\left(\mathbf{c d} / \mathbf{m}^{2}\right)\end{array}$ & $\begin{array}{l}\mathbf{L E}_{\max } \mathrm{c} \\
(\mathrm{cd} / \mathrm{A})\end{array}$ & $\begin{array}{c}\mathrm{EQE}_{\max }^{\mathrm{d}} \\
(\%)\end{array}$ & $\begin{array}{l}\mathrm{CIE}^{\mathrm{e}} \\
(\mathbf{x}, \mathrm{y})\end{array}$ \\
\hline $5: 5$ & 6 & 480 & 3.02 & 2.03 & $0.16,0.19$ \\
\hline $8: 2$ & 6.5 & 522 & 4.87 & 2.89 & $0.16,0.22$ \\
\hline $9: 1$ & 6.3 & 466 & 4.51 & 2.85 & $0.16,0.21$ \\
\hline $9.5: 0.5$ & 6.3 & 479 & 2.76 & 1.72 & $0.16,0.21$ \\
\hline $1: 0$ & 8 & 941 & 1.69 & 0.98 & $0.17,0.23$ \\
\hline \multicolumn{6}{|l|}{ aturn-on voltage } \\
\hline \multicolumn{6}{|l|}{${ }^{\mathrm{b}}$ maximum luminance } \\
\hline \multicolumn{6}{|c|}{${ }^{c}$ maximum current efficiency } \\
\hline \multicolumn{6}{|c|}{${ }^{d}$ maximum external quantum efficiency } \\
\hline
\end{tabular}

